\title{
DAR AL-'AHD WA AL-SHAHADAH: UPAYA DAN TANTANGAN MUHAMMADIYAH MERAWAT KEBINEKAAN
}

\author{
Hasnan Bachtiar
}

\begin{abstract}
Abstrak
Artikel ini mengkaji konsep Dar al-Ahd wa al-Shahadah (negara perjanjian dan persaksian) yang diajukan oleh Muhammadiyah. Konsep ini penting dikaji, karena merupakan konsep elaborasi antara doktrin Siyar - hukum perang dan hubungan internasional dalam tradisi Islam - dan Pancasila yang bertujuan: memberikan pedoman bagi para aktivis Muhammadiyah mengenai hubungan negara dan organisasi, sebagai fondasi pertahanan ideologis, sebagai alat harmonisasi politik, dan manifestasi intelektual dan politik yang menekankan pentingnya nasionalisme. Artikel ini secara argumentatif menyatakan bahwa melalui konsep tersebut, Muhammadiyah berupaya meredam laju gerakan Islamisme (termasuk populisme Islamis sebagai akibat dari faktor merebaknya Islamisme) di Indonesia. Secara implementatif, Muhammadiyah harus menghadapi pelbagai tantangan seperti konservatisme di lingkungan internal Muhammadiyah, infiltrasi ideologis (khususnya Islamisme) sehingga menyebabkan pemisahan diri dan pengerasan sikap keberagamaan, dan adanya kontestasi politik praktis musiman yang melibatkan pelbagai instrumentalisasi agama untuk kepentingan politik kekuasaan (populisme Islamis).
\end{abstract}


Kata Kunci: Muhammadiyah; Negara Pancasila; Dar al-'Ahd wa al-Shahadah; dar al-Islam; dar al-harb; Islamisme; Populisme Islamis; Islam Berkemajuan. ${ }^{1}$

\section{Pendahuluan}

Setelah terbitnya reformasi politik di tahun 1998, iklim politik Indonesia semakin terbuka. Partisipasi politik rakyat lebih signifikan dibandingkan dengan apa yang terjadi di masa Orde Baru. Secara lebih jauh, hal ini berlaku bukan hanya pada aspek politik praktis (real politik), namun juga pada gerakan sosial masyarakat sipil. Organisasi sosial tidak harus berdiri di atas azas tunggal Pancasila - yang sebelumnya secara otoritarian dan despotik dipaksakan oleh rezim Soeharto - tetapi tergantung kepada falsafah tertentu yang dikehendakinya. Argumentasi yang tampaknya paling masuk akal yang dianggap mampu menjelaskan hal tersebut adalah karena ruang publik semakin terbuka dan warga negara memiliki kesempatan secara merdeka berpartisipasi dalam pelbagai proses politik yang demokratis.

Dalam konteks tersebut, bermunculan banyak organisasi sosial Islam atau secara lebih luas adalah gerakan Islam, yang didirikan dengan nafas dan falsafah Islam. Gerakan-gerakan keagamaan ini menjadi pesaing baru pelbagai organisasi yang ada sejak Orde Baru. Bahkan, sebelum era kemerdekaan seperti Nahdlatul 'Ulama (NU), Muhammadiyah, Persatuan Islam (Persis) dan Al-Irsyad. Sebagian dari gerakan keagamaan baru ini telah tumbuh dan berkembang terlebih dahulu di Timur Tengah, seperti misalnya Hizbut Tahrir, Ikhwan al-Muslimin, Salafiyah dan Jama'ah Islamiyah. Menurut Azyumardi Azra, gerakan-gerakan tersebut merupakan gerakan Islam transnasional yang menyebar dari dunia Arab ke pelbagai pelosok belahan dunia lainnya, terutama Indonesia. ${ }^{2}$ Sementara itu, di antara gerakan-gerakan tersebut, berkembang pula organisasi keagamaan yang memiliki corak serupa, namun didirikan di dalam negeri, seperti misalnya Majelis Mujahidin Indonesia (MMI), Laskar

1 Artikel ini merupakan salah satu bab dari tesis Advanced Master yang "tidak diterbitkan" (2018) di Pusat Studi Arab dan Islam (Kajian Timur Tengah dan Asia Tengah), The Australian National University (ANU), Australia. Artikel ini merupakan versi yang diterjemahkan ke dalam bahasa Indonesia dan direvisi melalui beberapa pemutakhiran data. Penulis berterimakasih dan berhutang budi kepada Profesor James Piscatori yang berperan sebagai supervisor dalam proses penelitian.

2 Azyumardi Azra, "Islam in Shoutheast Asia: Tolerance and Radicalism," CSCI Islamic Issues Briefing Paper Series, The University of Melbourne, Melbourne, Australia, 2005, h. 1-23. 
Jihad dan Front Pembela Islam (FPI).

Gerakan-gerakan Islam transnasional tersebut, termasuk pula yang berdiri dan berkembang di Indonesia tetapi masih memiliki corak yang serupa, lebih banyak menampilkan pemikiran keagamaan yang cenderung konservatif dan bahkan radikal, disertai dengan kekerasan dan dalam kasus tertentu terlibat dalam aksiaksi terorisme. ${ }^{3}$ Sebenarnya, dengan demikian, reformasi politik di Indonesia bukan sekedar mendorong demokratisasi di mana nilai-nilai kebebasan dan kesetaraan semakin leluasa diakses oleh publik, namun juga memupuk benihbenih konservatisme dan radikalisasi keagamaan. Hal ini tampaknya selaras dengan refleksi yang diungkapkan oleh Sydney Jones, bahwa reformasi ternyata juga memiliki sisi gelap karena turut membuka pintu bagi intoleransi berbasis agama. $^{4}$

Secara lebih spesifik, argumentasi yang senantiasa diajukan oleh gerakan-gerakan keagamaan konservatif dan radikal ini adalah penolakannya terhadap sistem demokrasi, pentingnya mendirikan negara Islam dan penerapan syariat Islam. Menurut perspektif mereka, Negara Kesatuan Republik Indonesia bukanlah bentuk negara yang ideal, demikian pula dengan dasar negara Pancasila, sistem demokrasi Pancasila dan sistem hukum dan perundang-undangan Indonesia yang selama ini berlaku, dianggap bertolakbelakang dengan sistem Islam yang mereka kehendaki. ${ }^{5}$ Menurut perspektif fiqih klasik, Indonesia dipandang bukan sebagai negara Islam, bahkan tergolong sebagai negara perang (dar alharb). Konsekuensinya, mereka berinisiatif untuk mengupayakan perubahan Indonesia menjadi negara Islam (dar al-Islam). Masalahnya adalah, Islamisme ini tidaklah statis. Tetapi, terus-menerus bertransformasi secara dinamis. Islamisme pada derajat tertentu, turut mendorong lahirnya masalah-masalah baru seperti misalnya populisme Islamis. Hal ini teraktualisasi melalui pelbagai aksi massa yang menonjolkan identitas keislaman yang lebih lantang, formalistik, simbolik dan cenderung kritis terhadap rezim politik yang ada. Memang ada pelbagai faktor

3 Muhammad Tito Karnavian, Explaining Islamist Insurgencies: The Case of al-Jamaah al-Islamiyyah and the Radicalisation of the Poso Conflict 2000-2007, (London: Imperial College Press, 2015).

4 Sydney Jones, "Sisi Gelap Reformasi di Indonesia: Munculnya Kelompok Masyarakat Madani Intoleran," dlm. Sydney Jones et. al., Sisi Gelap Demokrasi: Kekerasan Masyarakat Madani di Indonesia, (Jakarta: PUSAD Paramadina, 2015), h. 3-29.

5 Lihat Greg Barton, Indonesia's Struggle, Jamaah Islamiyah and the Soul of Islam, (Sydney: University of New South Wales Press, 2004); Gregory Fealy dan Anthony Bubalo, Joining the Caravan: The Middle East, Islamism and Indonesia, (Alexandria, New South Wales: The Lowy Institute for International Policy, 2005); Burhanuddin Muhtadi, "The Quest for Hizbut Tahrir in Indonesia," Asian Journal of Social Science, Vol. 37, No. 4 (2009), h. 623-645; Muhammad Tito Karnavian, Explaining Islamist Insurgencies: The Case of al-Jamaah al-Islamiyyah and the Radicalisation of the Poso Conflict 2000-2007. 
yang kompleks, yang juga memicu munculnya populisme ini ke permukaan. Misalnya adalah instrumentalisasi politik yang timbul dari kontestasi oligarki dan reaksi kelas menengah terhadap peran-peran penting negara yang dianggap tidak mampu menjamin keadilan dan kesejahteraan rakyat.

Berhadapan dengan itu semua, Muhammadiyah mengklaim dirinya memiliki posisi yang berlawanan arah. Muhammadiyah menyatakan tidak sepaham dengan gerakan-gerakan Islam transnasional yang cenderung konservatif, terlebih yang radikal. Bagi Muhammadiyah, Islam harus dipahami sebagai agama yang berkemajuan, dalam pengertian mengedepankan cinta, welas asih, perdamaian, toleransi, persaudaraan, nir kekerasan dan berorientasi pembangunan peradabaan kemanusiaan yang luhur. Demikian pula terhadap populisme Islamis, kendati secara moral Muhammadiyah memperjuangkan nilai-nilai keadilan dan kesejahteraan, tetapi tidak sependapat dengan upaya mengkapitalisasi agama untuk kepentingan politik praktis, terlebih yang termanifestasikan dalam aksi politik yang menonjolkan identitas Islamisme yang formalistik. Karena itulah, maka secara lebih spesifik dan terbatas, artikel ini hendak melihat bagaimana Muhammadiyah sebagai promotor Islam Berkemajuan harus berhadapan dengan gerakan Islamisme dan populisme Islamis yang semakin merebak dewasa ini sejak bergulirnya reformasi politik pada dua dekade yang lalu.

Artikel ini berargumentasi bahwa, Muhammadiyah secara khusus berupaya meredam laju gerakan Islamisme di Indonesia, dengan mengampanyekan gagasan alternatif, yakni Negara Pancasila sebagai Dar al'Ahd wa al-Shahadah (negara perjanjian dan persaksian). Akan tetapi, dalam tataran implementatif, Muhammadiyah harus menghadapi tantangan-tantangan yang tidak mudah, seperti misalnya adanya sebagian kecil aktivis Muhammadiyah sendiri yang cenderung konservatif, adanya faktor eksternal yang memungkinkan infiltrasi ideologis sehingga menyebabkan pemisahan diri dan pengerasan sikap keberagamaan, dan adanya kontestasi politik praktis musiman yang melibatkan pelbagai instrumentalisasi agama untuk kepentingan politik kekuasaan (populisme Islamis). Secara lebih sistematis, artikel ini akan menjelaskan mengenai Muhammadiyah sebagai promotor Islam Berkemajuan, Negara Pancasila sebagai Dar al'Ahd wa al-Shahadah sebagai kontekstualisasi gagasan Islam Berkemajuan, dan tantangan-tantangan dalam mengimplementasikan gagasan alternatif Muhammadiyah tersebut. 


\section{Muhammadiyah sebagai Promotor Islam Berkemajuan}

Muhammadiyah berkhidmat dalam memperjuangkan Islam yang berkemajuan. Makna yang paling utama mengenai kredo tersebut adalah, Islam harus dipandang sebagai agama yang secara dinamis menjawab pelbagai masalah umat kekinian dan kedisinian. Secara lebih kontekstual, masalah-masalah yang dihadapi Muhammadiyah tersebut adalah krisis yang bersifat multi-dimensional di Indonesia yang berkisar mulai dari masalah sosial, politik, ekonomi dan kebudayaan, hingga keagamaan.

Sebagaimana yang telah diajukan Din Syamsuddin, Muhammadiyah berparadigma (wijhah) ${ }^{6}$ Islam Berkemajuan. ${ }^{7}$ Karakter yang ditonjolkan oleh paradigma Islam Berkemajuan ini adalah kosmopolitanisme atau berdiri di atas semua golongan melampaui keberbedaan warna kulit, suku, ras, agama, golongan, partai politik dan lain sebagainya. ${ }^{8}$ Karakter penting lainnya, sesuai dengan apa yang menjadi orientasi pada Muktamar Muhammadiyah ke-47 di Makassar 2015, adalah berorientasi penyelesaian masalah umat. ${ }^{9}$ Sementara itu, ada tiga karya intelektual penting yang secara spesifik mendiskusikan wacana Islam Berkemajuan: "Muhammadiyah Berkemajuan: Pergeseran dari Puritanisme ke Kosmopolitanisme" (2016), "Kosmopolitanisme Islam Berkemajuan" (2015), dan "Islam Berkemajuan untuk Peradaban Dunia: Refleksi dan Agenda Muhammadiyah ke Depan” (2015). ${ }^{10}$ Jika buku yang pertama menekankan bahwa Islam Berkemajuan bersifat dinamis, inspiratif dan futuristik terutama ketika berhadapan dengan tantangan zaman, mengedepankan ortopraksi keagamaan ketimbang ortodoksi, menghormati

6 Din Syamsuddin, "Gerakan Pencerahan Menuju Indonesia Berkemajuan: Refleksi, Proyeksi dan Rekomendasi," dlm. Abdul Mu'ti et. al. (eds.), Kosmopolitanisme Islam Berkemajuan, (Surakarta: Muhammadiyah University Press, 2015), h. 11.

7 Abdul Mu'ti et. al. (eds.), Kosmopolitanisme Islam Berkemajuan, (Surakarta: Muhammadiyah University Press, 2015).

8 Karakter kosmopolitan Muhammadiyah menurut pandangan Burhani adalah inklusif dan terbuka (open-minded). Lihat Ahmad Najib Burhani, Muhammadiyah Berkemajuan: Pergeseran dari Puritanisme ke Kosmopolitanisme, (Bandung: Mizan, 2016), h. 43; Lihat juga Pimpinan Pusat Muhammadiyah, Tanfidz Keputusan Muktamar Satu Abad Muhammadiyah, (Yogyakarta: Pimpinan Pusat Muhammadiyah, 2010).

9 Pimpinan Pusat Muhammadiyah, Tanfidz Keputusan Muktamar Satu Abad Muhammadiyah, h. 13.

10 Ahmad Najib Burhani, Muhammadiyah Berkemajuan: Pergeseran dari Puritanisme ke Kosmopolitanisme; Hajriyanto Thohari, "Trisula Baru Gerakan Muhammadiyah," dlm. Abdul Mu'ti et. al. (eds.), Kosmopolitanisme Islam Berkemajuan, h. 329-333; Sudarnoto Abdul Hakim, "Muhammadiyah dan Kebudayaan Kita," dlm. Alpha Amirrachman, Andar Nubowo and Azaki Khoiruddin (eds.), Islam Berkemajuan untuk Peradaban Dunia, h. 5067. 
waktu dan kerja keras ${ }_{11}^{11}$ menurut buku yang kedua, Muhammadiyah dianggap bergerak oleh karena motivasi iman (faith in action). ${ }^{12}$ Sementara itu dalam buku yang terakhir, Muhammadiyah bergerak secara dinamis oleh karena spirit tajdad (reformation) yang menginspirasi pembangunan pelbagai bidang kehidupan lainnya. ${ }^{13}$

Sedangkan menurut Ketua Umum Pimpinan Pusat (PP) Muhammadiyah, Haedar Nashir, Islam Berkemajuan merupakan gagasan keagamaan yang mengedepankan praksis humanisme universal. ${ }^{14}$ Di saat yang sama, mantan Ketua Umum PP Muhammadiyah, Din Syamsuddin, ide Islam Berkemajuan haruslah secara terus-menerus dalam rangka memastikan relevansinya di hadapan situasi dan kondisi kontemporer. ${ }^{15}$ Dalam benaknya, gagasan ini begitu penting untuk menyelesaikan masalah-masalah baru yang timbul di tengah-tengah masyarakat. Ia menambahkan, pada akhirnya, ketika tidak ada agenda dinamisasi, gagasan kehilangan vitalitas dan kemampuannya dalam menyelesaikan masalah-masalah baru tersebut. Pendek kata, dari pelbagai pendapat para tokoh Muhammadiyah, jelaslah bahwa Islam Berkemajuan memiliki sifat tertentu, yakni dinamis dan transformatif. Meskipun para pemikir Muslim lainnya, seperti misalnya Omid Safi, membicarakan konsep yang serupa dan menekankan bahwa hal tersebut harus mendorong kaum Muslim agar supaya lebih peduli terhadap permasalahan keadilan dan pluralisme, ${ }^{16}$ gagasan Muhammadiyah mengenai 'kemajuan' sebenarnya juga mengupayakan ijtihad dalam rangka menghadapi isu-isu pembangunan kemanusiaan lainnya yang lebih pelik, seperti kemiskinan, pendidikan dan pemberdayaan masyarakat yang dalam konteks ini tidak dijangkau oleh para pemikir Muslim lainnya.

Bagi Muhammadiyah, dengan menyebut bahwa Islam Berkemajuan bukanlah sekedar gagasan keagamaan namun juga inspirasi bagi gerakan sosial, hal itu haruslah diwujudkan dalam pelbagai realitas yang konkret. Menurut Syamsuddin,

11 Teologi Al-Ma'un adalah konsep teologis yang menekankan nilai-nilai penting bermasyarakat dan menjunjung tinggi kemanusiaan yang disarikan dari al-Qur'ān, Surah Al-Ma'un. Sementara Teologi Al-'Ashr menekankan pentingnya spirit bekerja keras dan menghormati waktu yang diadopsi dari Surah Al-'Ashr. Lihat Ahmad Najib Burhani, Muhammadiyah Berkemajuan: Pergeseran dari Puritanisme ke Kosmopolitanisme, h. 45-48.

12 Hajriyanto Thohari, "Trisula Baru Gerakan Muhammadiyah."

13 Ibid., Hajriyanto Thohari.

14 Haedar Nashir, "Muktamar Teladan dan Muhammadiyah Berkemajuan," dlm. Abdul Mu'ti et. al. (eds.), Kosmopolitanisme Islam Berkemajuan, h. 9.

15 Din Syamsuddin, "Gerakan Pencerahan Menuju Indonesia Berkemajuan: Refleksi, Proyeksi, dan Rekomendasi," dlm. Abdul Mu'ti et. al. (eds.), Kosmopolitanisme Islam Berkemajuan, h. 12.

16 Omid Safi, Progressive Muslims: On Justice, Gender and Pluralism, (Oxford: Oneworld, 2003), h. 2. 
Muhammadiyah sebagai agensi pembangunan peradaban memiliki cita-cita untuk mewujudkan Indonesia sebagai negara dan bangsa yang 'berkemajuan' pula. ${ }^{17}$ Hal ini tentu bukanlah hal yang mengejutkan apabila ada yang mengatakan bahwa Muhammadiyah menunjukkan dirinya sebagai sebuah organisasi yang mengombinasikan antara ortodoksi dan ortopraksi sekaligus, di mana yang terakhir disebutkan tersebut melibatkan adanya bentuk aktivisme sosial. ${ }^{18}$

Zakiyuddin Baidhawy berargumentasi bahwa kombinasi antara ortodoksi dan ortopraksi dimotivasi oleh dua teologi penting di dalam Muhammadiyah, yakni teologi puritanisme dan teologi al-Ma'un. ${ }^{19}$ Jika yang pertama memberikan perhatian khusus terhadap pentingnya merujuk kepada sumber-sumber utama Islam, maka yang terakhir bermakna bahwa Islam haruslah bermanfaat bagi masyarakat dan kemanusiaan. ${ }^{20}$ Baidhawy menjelaskan bahwa pemikiran keagamaan haruslah diitegrasikan dengan aktivitas-aktivitas sosial demi menjamin bahwa hal tersebut berdaya guna bagi kemanusiaan, terutama bagi golongan lemah dan mereka yang termarjinalkan (mustad'afin). ${ }^{21}$ Sejak 2015, ada pula tren teologi baru yang dikembangkan di dalam Muhammadiyah, yakni 'Teologi Al-'Ashr'. Menurut Azaki Khoiruddin, ini adalah bentuk teologi yang menegaskan pentingnya etos aktivisme di lingkungan Muhammadiyah yang menekankan spirit kerja keras, menghormati pentingnya waktu, dan juga peduli terhadap masalah pembangunan bangsa demi kehidupan generasi mendatang. ${ }^{22}$ Jadi, ortopraksi Muhammadiyah memiliki makna lebih dari sekedar mengenai perilaku keagamaan tertentu (religious-validated behaviour); akan tetapi juga menyangkut masalah aktivisme sosial yang selaras dengan etos keagamaan.

Berkaitan dengan segala pengertian tersebut, sesungguhnya gagasan mengenai Islam Berkemajuan itu sendiri mendorong Muhammadiyah agar melibatkan dirinya untuk menyelesaikan segala masalah kekinian bangsa ini. Di dalam

17 Ibid., Din Syamsuddin, "Gerakan Pencerahan Menuju Indonesia Berkemajuan."

18 Moeslim Abdurrahman, Islam sebagai Kritik Sosial, (Jakarta: Erlangga, 2003), h. 123; Herman L. Beck, "The Borderline between Muslim Fundamentalism and Muslim Modernism: An Indonesian Example," dlm. Jan Willem van Henten dan Anton Houtepen (eds.), Religious Identity and the Invention of Tradition, (Assen, the Netherland: Royal Van Gorcum, 2001), h. 286.

19 Zakiyuddin Baidhawy, "The Muhammadiyah's Promotion of Moderation," The American Journal of Islamic Social Sciences, Vol. 32, Issue 3 (2015), h. 69-91.

20 Zakiyuddin Baidhawy, "The Muhammadiyah's Promotion of Moderation."

21 Ibid., Zakiyuddin Baidhawy, h. 84.

22 Azaki Khoirudin, Teologi al-'Ashr: Etos dan Ajaran KHA Dahlan yang Terlupakan, (Yogyakarta: Suara Muhammadiyah, 2015). 
dokumen resminya, Muhammadiyah mengakui bahwa Indonesia sedang menghadapi pelbagai krisis yang bersifat multi-dimensional. ${ }^{23} \mathrm{Di}$ antara masalahmasalah yang disoroti oleh Muhammadiyah tersebut adalah neoliberalisme, korupsi, ketidakadilan, ketidaksetaraan, disparitas sosial, kemiskinan dan juga pelbagai isu keagamaan yang sensitif seperti konservatisme, radikalisme, dan terorisme Islamis. Negara tentu harus menghadapi pelbagai masalah krusial tersebut, namun Muhammadiyah - terutama melalui pelbagai institusi pendidikan tingginya (Perguruan Tinggi Muhammadiyah/PTM) - secara aktif menegaskan bahwa dirinya secara khusus memiliki tanggungjawab nasional kebangsaan, yang juga bisa dianggap sebagai tanggungjawab keagamaan. Salah satu PTM yang dimiliki Muhammadiyah, yakni Universitas Muhammadiyah Malang, sebagai contoh, aktif berkampanye dengan slogan "Dari Muhammadiyah untuk Bangsa.” Dari sini, penting kiranya melihat bagaimana kredo Islam Berkemajuan tersebut dikontekstualisasikan oleh Muhammadiyah secara lebih nyata.

\section{Kontekstualisasi Islam Berkemajuan:}

\section{Negara Pancasila sebagai Dar al-'Ahd wa al-Syahadah}

Salah satu kontekstualisasi terpenting dari gagasan fundamental Islam Berkemajuan yang diupayakan Muhammadiyah adalah Dar al-'Ahd wa alShahadah. Artinya, Indonesia yang sebenarnya merupakan Negara Pancasila, dipandang sebagai negara perjanjian (daral-ahd) dan persaksian (al-shahadah). Hal itu bertujuan untuk memberikan pedoman bagi para aktivis Muhammadiyah mengenai hubungan negara dan persyarikatan, sebagai fondasi pertahanan ideologis, sebagai alat harmonisasi politik, dan manifestasi intelektual dan politik yang menekankan pentingnya nasionalisme kebangsaan.

Menurut dokumen resmi Muhammadiyah, organisasi tersebut memandang bahwa Republik Indonesia yang berdiri di atas landasan Pancasila (Negara Pancasila) merupakan Dar al-Ahd wa al-Shahadah. Negara Pancasila disebut sebagai dar al-'ahd (negara perjanjian atau negara kesepakatan), ${ }^{24}$ karena

23 Pimpinan Pusat Muhammadiyah, Indonesia Berkemajuan: Rekonstruksi Kehidupan yang Bermakna, (Yogyakarta: Pimpinan Pusat Muhammadiyah, 2015), h. 17-28.

24 Dār al-'ahd secara literal bermakna tanah kesepakatan atau perjanjian. Hal itu dikonseptualisasi oleh al-Shafi'i untuk menengahi teritori antara dar al-Islam dan dar al-harb. Lihat bab sebelumnya. Lihat juga Halil İnalcık, "Dār al-Ahd," dlm. P. Bearman, Th. Bianquis, C.E. Bosworth, E. van Donzel, W.P. Heinrichs (eds.), Encyclopaedia of Islam, Second Edition, Consulted online on 03 September 2018 http://dx.doi.org/10.1163/1573-3912_islam_ SIM_1698 (Diakses 6 September 2018). Dalam pandangan Muhammadiyah, hal itu diterjemahkan secara konsisten sebagai 'konsensus'. 
berdirinya di tahun 1945 dan perumusan dasar-dasarnya dihasilkan dari sebuah konsensus nasional. ${ }^{25}$ Lantas kemudian, penambahan dar al-shahadah (negara persaksian) setelah dar al-'ahd, bermakna bahwa implementasi mengenai (nilainilai luhur) Pancasila memerlukan peran aktif Muhammadiyah. Karena itulah maka Muhammadiyah akan menyaksikan dirinya sebagai bagian dari Indonesia dan menjadi Indonesia itu sendiri (Muhammadiyah adalah Indonesia). ${ }^{26}$

Berkaitan erat dengan gagasan dar al-'ahd, secara historis, ketika Pancasila direformulasikan melalui konsensus nasional, para tokoh bangsa yang memiliki peran begitu penting pada saat itu, terutama sebagian dari mereka adalah para elit Muhammadiyah yang membawa serta aspirasi kaum Muslim, memahami bahwa Pancasila selaras dan berjalan beriringan dengan ajaran-ajaran Islam. ${ }^{27}$ Ketika Indonesia secara ideal mengidamkan agar supaya menjadi negara yang aman, tentram dan damai (yang dalam bahasa Arab lazim dipahami sebagai dar al-salam), juga sebagai negara yang maju, adil, sejahtera, bermartabat dan berdaulat, sebenarnya segala tujuan ini selaras dengan tujuan Islam sebagaimana halnya yang dipahami oleh Muhammadiyah - yakni yang dikenal dengan istilah mewujudkan "baldatun thayyibatun wa rabbun ghafûr" (negara yang adil, makmur dan sejahtera, yang berada di bawah naungan rahmat dan ampunan Tuhan). ${ }^{28}$

25 Pimpinan Pusat Muhammadiyah, Negara Pancasila sebagai Darul Ahdi wa Syahadah, (Yogyakarta: Pimpinan Pusat Muhammadiyah, 2015), h. 12.

26 Ahmad Syafii Maarif, salah seorang mantan Ketua Pimpinan Pusat Muhammadiyah, secara reflektif berpendapat bahwa mengklaim Indonesia hanya sekedar sebagai negara perjanjian atau konsensus tidaklah cukup; penting kiranya untuk mereformulasikan juga Indonesia sebagai negara persaksian (dār al-shahādah). la secara retoris menyatakan bahwa, "meskipun tidak ada konsep seperti itu di dalam ilmu politik dalam tradisi Islam (figh al-siyāsah), kita bertanggungjawab - yang selaras dengan argumentasi kita mengenai syahadat (teologis) di dalam Islam, terutama bahwa kita adalah masyarakat yang moderat (ummatan wasatan), yang pengejawantahannya bermakna realisasi dan mewujudkannya secara materiil." Argumentasi ini berpijak di atas landasan Qur'ani yakni, "Kami menginginkan engkau agar supaya menjadi ummah yang moderat" (wakadhalika ja'alnākum ummatan wasatan), lantas hal tersebut mengikuti frase bahwa, "itu semua bertujuan menjadikanmu sebagai saksi" (litakūnu syuhadā'). Berkaitan dengan argumentasi ini, secara lebih jauh, Maarif mendorong semua aktivis Muhammadiyah untuk berpartisipasi aktif dalam mewujudkan (merealisasikan dan mematerialisasikan) syahadat atau persaksiannya tersebut, sebagai sebuah syahadat kebudayaan, syahadat keyakinan, syahadat peradaban dan syahadat kebangsaan. Ahmad Syafii Maarif dlm. narasi tekstual Din Syamsuddin. Lihat Din Syamsuddin, "Tafsir Islam atas Negara Pancasila," dlm. Muamaroh and Benni Setiawan (eds.), Negara Pancasila, Darul 'Ahdi Wasy-Syahadah: Perspektif Teologis dan Ideologis, (Yogyakarta: Majelis Pendidikan Kader Pimpinan Pusat Muhammadiyah, 2017), h. 161-162.

27 Haedar Nashir, "Muhammadiyah Membangun Integrasi Keislaman dan Kebangsaan Menuju Indonesia Berkemajuan," dlm. Faozan Amar et.al. (eds.), Darul-Ahdi Wasy-Syahadah: Konteks, Makna dan Aktualisasi untuk Indonesia Berkemajuan, (Jakarta: Al-Wasat Publishing House, 2018), h. 23; Lihat Din Syamsuddin, "NKRI: Negara Perjanjian dan Kesaksian," dlm. Akhmad Sahal and Munawir Aziz (eds.), Islam Nusantara: Dari Ushul Figh Hingga Konsep Historis, (Bandung: Mizan, 2015), h. 282; Mengenai sejarah para elit Muhammadiyah beserta segala kontribusinya dalam pendirian negara Indonesia dan perumusan Pancasila, lihat Lukman Hakiem (ed.), Dari Muhammadiyah untuk Indonesia: Pemikiran dan Kiprah Ki Bagus Hadikusumo, Mr Kasman Singodimedjo, dan KH Abdul Kahar Mudzakkir, (Yogyakarta: Pimpinan Pusat Muhammadiyah, 2013).

28 Haedar Nashir, "Muhammadiyah Membangun Integrasi Keislaman dan Kebangsaan Menuju Indonesia Berkemajuan," pp. 20-21. 
Melalui formulasi dar al'ahd, dalam mempertimbangkan wacana mengenai Siyar klasik, Syamsuddin berpendapat bahwa pemikiran dikotomistik yang membagi dunia menjadi dar al-Islam (negara Islam) dan dar al-harb (negara perang) sudahlah tidak lagi relevan di hadapan konteks globalisasi modern. ${ }^{29}$ Alasannya adalah, Indonesia juga merupakan bagian dari sistem internasional negara bangsa, secara moral dan politis mesti menghormati realitas keberagaman yang global. Sebagai konsekuensinya, ia menekankan bahwa Indonesia terikat dengan pelbagai kesepakatan atau perjanjian internasional pada level yang lebih tinggi. Hal ini sejalan dengan posisi Muhammadiyah yang juga terikat dengan kesepakatan nasional yang memiliki otoritas yang lebih tinggi pula. ${ }^{30}$ Secara lebih jauh, Syamsuddin dengan berpijak pada pendekatan Hegelian menjelaskan mengenai masalah konsensus nasional tersebut. Menurut elaborasinya, ia menyatakan bahwa Muhammadiyah haruslah selaras dengan konsensus yang merefleksikan titik temu dua jenis kebebasan (kemerdekaan), yakni kemerdekaan yang subyektif dan obyektif. ${ }^{31}$ Ketika yang pertama lebih merupakan kebebasan yang disampaikan oleh individu dalam satu kelompok masyarakat tertentu - dalam konteks ini adalah sebuah organisasi Muslim seperti misalnya Muhammadiyah -, yang kedua merupakan hasil partisipasi seluruh orang bangsa, termasuk kaum Muslim. ${ }^{32} \mathrm{Jadi}$, Pancasila dalam pengertian ini merupakan kesepakatan bersama (common platform) bangsa Indonesia dan juga intisari (kesamaan) dari hal-hal yang disepakati tersebut (common denominator) yang mengakomodir nilai-nilai dari pelbagai agama (shared values of various religions) dalam rangka menjamin kehidupan rakyat banyak dalam naungan kesatuan kebangsaa. ${ }^{33}$

Sebagaimana disebutkan sebelumnya, bahwa Negara Pancasila bukan sekedar bermakna dar al-ahd, namun juga dar al-shahadah. Haedar Nashir berpendapat, adanya konsep ini berimplikasi bahwa kaum Muslim perlu melibatkan diri mereka dalam mewujudkan cita-cita negara Indonesia. Dalam konteks ini, mereka berperan sebagai para aktor utama yang menyaksikan (shahadah)

29 Din Syamsuddin, "Tafsir Islam atas Negara Pancasila," p. 161.

30 Ibid., Din Syamsuddin.

31 Ibid

32 Ibid. Dengan menggunakan formulasi yang berbeda, Syamsuddin berpendapat bahwa, berdirinya Republik Indonesia yang berlandaskan kepada Pancasila merupakan kristalisasi dari segala cita-cita ideal bangsa yang secara kultural sangatlah beragam. Oleh karenanya, Indonesia hadir sebagai titik temu antara kebebasan subyektif dan obyektif dari seluruh elemen kebangsaan. Dengan pengertian lain, hal itu merupakan pertemuan pelbagai pemikiran dalam elemen-elemen tersebut. Lihat Din Syamsuddin, "NKRI: Negara Perjanjian dan Kesaksian," h. 279.

Din Syamsuddin, "NKRI: Negara Perjanjian dan Kesaksian," h. 279. 
segala upaya yang mereka lakukan beserta hasilnya. Inspirasi mengenai hal ini diambil dari frase Qur'ani, "shahadah 'ala al-nas” (para penyaksi di antara umat manusia). ${ }^{34} \mathrm{Hal}$ itu tentu saja mendorong kaum Muslim secara lebih jauh untuk memperteguh komitmen mereka dalam rangka berkontribusi dalam pembangunan Indonesia di segala bidang dan dimensi kehidupan, dan juga di segala jalan yang adil dan luhur (fastabiq al-khairat). Dengan demikian maka, Indonesia akan menjadi salah satu dari pada peradaban-peradaban di tengahtengah kompetisi global. ${ }^{35}$ Implementasi dari konsep ini secara fundamental berdiri di atas prinsip-prinsip meritokrasi dan proporsionalitas, oleh karena adanya pelbagai peran yang berbeda di antara masyarakat. ${ }^{36}$

Ada beberapa alasan mengapa Muhammadiyah memproklamirkan gagasan mengenai Negara Pancasila sebagai Dar al-Ahd wa al-Shahadah, yakni sebagai pedoman, sebagai benteng ideologis, sebagai penguat hubungan politis antara negara dan Muhammadiyah, dan manifesto intelektual dan politik Muhammadiyah.

Pertama, sebagai pedoman, gagasan ini "ditujukan sebagai rujukan dan orientasi pemikiran dan aksi bagi seluruh anggota Muhammadiyah khususnya dalam pembangunan bangsa dan negara yang berlandaskan pada 'Islam Berkemajuan' sebagai perspektif Muhammadiyah." 37 Menurut Hajriyanto Thohari, formalisasi gagasan ini "adalah agar supaya Muhammadiyah menjadi lebih proaktif dan progresif dalam membangun bangsa, sebagaimana yang telah dicontohkan oleh para generasi pendahulu." ${ }^{38}$ Di samping itu, meskipun gagasan Negara Pancasila telah disepakati dan diresmikan setelah kemerdekaan Indonesia, institusionalisasi Dar al-Ahd wa al-Shahadah sangatlah penting untuk mencegah adanya ketidakjelasan atau ambivalensi posisi Muhammadiyah sendiri di hadapan negara. ${ }^{39}$ Syamsuddin menyatakan secara lebih jauh bahwa, oleh

34 Haedar Nashir, "Muhammadiyah Membangun Integrasi Keislaman dan Kebangsaan Menuju Indonesia Berkemajuan," h. 20-21.

35 Pimpinan Pusat Muhammadiyah, Negara Pancasila sebagai Darul Ahdi wa Syahadah, h. 13-14.

36 Din berpendapat bahwa warga negara Indonesia harus berjuang untuk negaranya sebagai perwujudan komitmen mereka dalam rangka mewujudkan cita-cita kebangsaan, sekurang-kurangnya berusaha menjadi warga negara yang baik, taat hukum dan konstitusi NKRI: Negara Perjanjian dan Kesaksian," h. 284-285.

37 Pimpinan Pusat Muhammadiyah, Negara Pancasila sebagai Darul Ahdi wa Syahadah, h. iii.

38 Wawancara dengan Hajriyanto Thohari, salah seorang ketua Pimpinan Pusat Muhammadiyah, 21 Agustus 2018.

39 Din Syamsuddin, "Tafsir Islam atas Negara Pancasila," h. 160. 
karena gagasan ini berkaitan erat dengan masalah negara dan bangsa, maka hal tersebut dianggap sebagai hal yang bersifat politis. Akan tetapi di saat yang sama, oleh karena hal tersebut melibatkan peran-peran kaum Muslim, maka dianggap bersifat keagamaan (religius). ${ }^{40}$ Meminjam istilah Thohari, hal itu adalah ijtihad Muhammadiyah yang benar-benar otentik. ${ }^{41}$

Kedua, gagasan ini dimaksudkan sebagai sebuah benteng ideologis bagi Muhammadiyah. Muhammadiyah menjadikan gagasan tersebut sebagai proteksi ideologis dalam menghadapi masalah merebaknya Islamisme yang begitu massif. ${ }^{42}$ Sebagaimana yang secara kritis dipertimbangkan oleh Abdul Mu'ti, para Islamis - termasuk mereka yang ada di dalam Muhammadiyah - berpotensi berperilaku subversif, terutama sejak mereka cenderung menolak prinsip-prinsip Pancasila dan sistem pemerintahan yang selama ini berlaku, dan juga mereka menyatakan adanya keinginan yang kuat untuk mendirikan negara Islam..${ }^{43}$ Di dalam Muktamar Muhammadiyah, Saad Ibrahim menjelaskan bahwa gagasan Negara Pancasila sebagai Dar al-Ahd wa al-Shahadah merupakan gagasan yang sedemikian penting, karena Muhammadiyah harus berhadap-hadapan dengan konteks pelbagai tantangan berbasis keagamaan. ${ }^{44}$ Sejalan dengan pertimbangan Mu'ti sebelumnya, ia sebenarnya khawatir bahwa Muhammadiyah akan dipandang sebagai organisasi atau gerakan yang mirip dengan Wahabisme modern dalam pengertian konservatisme keagamaan dan bahkan dalam tingkatan tertentu, radikalisme. ${ }^{45}$

Ada beberapa kasus yang krusial untuk diperhatikan di sini. Pada 1953, gagasan Indonesia sebagai dar al-Islam (bukan dar al-ahd) pernah ditawarkan pertama kali pada Muktamar Muhammadiyah ke-32 di Purwokerto. Sebagian muktamirin

40 Din Syamsuddin, "NKRI: Negara Perjanjian dan Kesaksian," h. 281.

41 Hajriyanto Thohari menyatakan bahwa Dar al-'Ahd wa al-Shahadah suatu hal "yang lebih dari sekedar legitimasi politik." Hal tersebut, baginya, merupakan "sebuah manifestasi otentik dari upaya yang sungguh-sungguh dalam pemikiran keagamaan." Wawancara dengan Hajriyanto Thohari.

42 Ada beberapa varian Islamisme. Akan tetapi, menurut perspektif Muhammadiyah, jenis Islamisme yang haruslah ditantang adalah yang konservatif dan bersifat revolusioner atau biasanya disebut sebagai Islamisme militan (sebagian kalangan menyebutnya sebagai Islamisme radikal atau jihadis). Kategori Islamisme tersebut telah disebutkan beberapa kali di pelbagai Dokumen Resmi Persyarikatan dan salah satunya adalah di dalam dokumen "Negara Pancasila sebagai Darul Ahdi aa Syahadah" (2015) karangan Pimpinan Pusat Muhammadiyah. Kategori ini mirip dengan konsep Islamisme yang ditawarkan oleh Asef Bayat. Lihat Asef Bayat, "Post-Islamism at Large," dlm. Asef Bayat (ed.), Post-Islamism: The Changing Faces of Political Islam, (Oxford: Oxford University Press, 2013), h. 5-7.

43 Abdul Mu'ti sebagaimana yang dikutip oleh Faozan Amar dan Dinan Hasbudin Apip, "Darul-'Ahdi WasySyahadah: Makna dan Implementasi," dlm. Faozan Amar et.al. (eds.), Darul-Ahdi Wasy-Syahadah: Konteks, Makna dan Aktualisasi untuk Indonesia Berkemajuan, h. 13.

44 Wawancara dengan Saad Ibrahim.

45 Ibid., 
yang hadir menghendaki Muhammadiyah agar supaya mengonseptualisasikan negara Islam. Dalam rangka menindaklanjuti tuntutan ini, konsep mengenai hal tersebut telah diformulasikan oleh Abdul Kahar Muzakir dalam "Tanwir Muhammadiyah” di Pekalongan pada 1955. Menurut pandangannya, negara Islam adalah negara yang dipimpin oleh seorang pemimpin Muslim dan menerapkan hukum Islam. ${ }^{46}$ Akan tetapi, sebagaimana yang diamati oleh Amin Abdullah, ada pelbagai penafsiran yang sebenarnya bersifat "eksklusif, tertutup, sektarian, primordial, parokial.” ${ }^{47}$ Zakiyuddin Baidawy menggarisbawahi pelbagai kelompok yang mengajukan pelbagai gagasan alternatif (garis keras). Ia menyebut pelbagai kelompok seperti Negara Islam Indonesia (NII), Hizbut Tahrir Indonesia (HTI), Majelis Mujahidin Indonesia (MMI), Jamaah Anshorut Tauhid (JAT) dan Jamaah Anshorut Daulah (JAD). Secara ambisius, masingmasing menginginkan untuk mendirikan negara Islam oleh karena Indonesia dipandang sebagai negara yang tidak Islami dan Pancasila merupakan ideologi setan (thogut). ${ }^{48}$ Di samping itu, terdapat fakta pula bahwa ada sekitar 500-700 para jihadis dari Indonesia yang bergabung dengan Negara Islam Irak dan Suriah (the Islamic State of Iraq and Syria) (ISIS)” .

Berkaitan erat dengan pelbagai kasus tersebut di atas, Syamsuddin menyatakan bahwa "Di era demokratis ini, setiap ide atau aspirasi dari seseorang atau sekelompok orang tentu dapat diterima (merdeka untuk diekspresikan) sepanjang hal tersebut disampaikan melalui prosedur dan mekanisme yang konstitusional, tidak koersif dan tidak disertai dengan kekerasan." ${ }^{49}$ Berkaitan dengan tuduhan bahwa Pancasila adalah ideologi setan, kafir dan tidak Islami, ia berpendapat bahwa "Gagasan ini merupakan sebuah ancaman dan bahkan dapat dikategorikan sebagai subversi terhadap negara... Pendekatan ini tentu saja merupakan sebuah pengkhianatan terhadap konsensus nasional." 50

Ketiga, gagasan ini bertujuan untuk memperkuat hubungan politik antara negara dan Muhammadiyah sebagai sebuah organisasi masyarakat sipil. Upaya

46 Menurut Ahmad Imam Mujadid Rais, seorang peneliti MAARIF Institute, secara historis Muhammadiyah adalah anggota khusus dari Masyumi dan perdebatan mengenai Pancasila sebenarnya sedang berlangsung bahkan hingga hal tersebut diformalisasikan di dalam rapat kedua BPUPKI. Lihat Ahmad Imam Mujadid Rais, "Pengantar Redaksi," MAARIF, Vol. 11, No. 1 (2016), h. 8-9.

47 Amin Abdullah, "Agama dan Pancasila dalam Identitas Keindonesiaan," in Muamaroh and Benni Setiawan (eds.), Negara Pancasila, Darul 'Ahdi Wasy-Syahadah: Perspektif Teologis dan Ideologis, h. 85.

48 Zakiyuddin Baidhawy, "Pancasila Tauhid Sosial dalam Kehidupan Berbangsa dan Bernegara," MAARIF, Vol. 11, No. 1 (2016), h. 42.

49 Din Syamsuddin, "NKRI: Negara Perjanjian dan Kesaksian," h. 282.

50 Ibid., Din Syamsuddin. 
penguatan politik ini setidaknya dapat diartikulasikan melalui tiga jalan yang berbeda, yakni realpolitik (politik praktis), filsafat (moral) dan kebangsaan. Menurut sudut pandang realpolitik, hubungan di antara kedua agensi politik tersebut tampak merenggang dari waktu ke waktu. Pada periode politik masa lalu sejak tahun 1980an hingga saat ini, kader-kader terbaik Muhammadiyah menduduki pelbagai posisi politik yang strategis, baik itu di lembaga-lembaga eksekutif, legislatif maupun yudikatif. ${ }^{51}$ Dengan posisi mereka itu, mereka berkontribusi pada pelbagai aktivitas dan kebijakan kenegaraan. ${ }^{52}$ Akan tetapi, pada periode 2014-2019, hanya ada satu representasi Muhammadiyah yang duduk di kabinet Presiden Joko Widodo; ${ }^{53}$ yakni di tahun 2016, Muhadjir Effendy, seorang aktivis Muhammadiyah garda depan, diangkat sebagai Menteri Pendidikan dan Kebudayaan (Mendikbud) menggantikan Anies Baswedan.

Secara filosofis, sebagaimana yang telah ditegaskan oleh Haedar Nashir, Dar al'Ahd wa al-Shahadah bertujuan mengintegrasikan antara nilai-nilai keislaman dan keindonesiaan. ${ }^{54}$ Ia berargumentasi bahwa, Islam itu sendiri adalah agama yang berkemajuan dan secara potensial dapat mendorong pembangunan peradaban (dar al-hadarah), dan oleh karena itu, maka Muhammadiyah menjadi bagian atau menyatu dengan negara dan bangsa ini dalam rangka mengimplementasikan nilai-nilai kemajuan. ${ }^{55}$ Inilah mengapa, ia menambahkan, ketika Islam dipahami sebagai agama yang berkemajuan, Islam akan mampu menyesuaikan diri dengan segala konteks kehidupan yang dinamis. Oleh karena itu, maka sebenarnya doktrin klasik Siyar (pemisahan antara dar al-Islam dan dar al-harb) haruslah direformasi atau setidaknya direvitalisasi agar selaras dengan watak dan karakter bangsa Indonesia. ${ }^{56}$

Sementara itu, menurut Azaki Khoiruddin, seorang aktivis muda

51 Syarifuddin Jurdi, Muhammadiyah dalam Dinamika Politik Indonesia 1966-2006, (Yogyakarta: Pustaka Pelajar, 2010), h. 461-483

52 Sebagai contoh, para tokoh Muhammadiyah terkemuka, sebagai misalnya Abdul Mukti Ali pernah menjadi Menteri Agama (1973-1978), Abdul Malik Fadjar menjadi Menteri Agama (1998-1999) dan Menteri Pendidikan Nasional (2001-2004), Bambang Sudibyo menjadi Menteri Keuangan (1999-2000) dan Menteri Pendidikan Nasional (2004-2009), dan Yahya Muhaimin adalah Menteri Pendidikan Nasional (1999-2001).

53 Ahmad Najib Burhani, "Absennya Muhammadiyah dalam Kabinet Kerja Jokowi-JK," Koran SINDO, Kamis, 13 November 2014.

54 Haedar Nashir, "Muhammadiyah Membangun Integrasi Keislaman dan Kebangsaan Menuju Indonesia Berkemajuan," h. 25. 
Muhammadiyah, gagasan ini bermakna sebagai jembatan hubungan sosialpolitis (silaturrahmi) antara penguasa (atau pemerintah) dan para aktivis muda. ${ }^{57}$ Alasannya adalah, mereka (kaum muda) berpikir bahwa mereka tidak memiliki hubungan yang baik dengan pemerintah, karena menurut mereka melalui tuturan Khoiruddin - pemerintah Indonesia bukanlah institusi yang Islami. Menurut pandangan mereka, di mana Khoiruddin adalah salah satu representasinya, pemerintah secara nyata tidak menerapkan nilai-nilai keislaman dan keindonesiaan secara benar. Para aktivis muda dihinggapi ketidakpercayaan terhadap pemerintah, karena banyaknya kasus korupsi yang melanda, lalu lemahnya penegakan hukum bahkan di kalangan para pejabat negara, dan juga kebijakan publik pemerintah yang mereka percaya sebagai hal yang tidak memprioritaskan kesejahteraan rakyat. Berdasarkan pada hal-hal tersebut, para aktivis muda ingin memberikan sesuatu yang bernilai dan bermanfaat bagi bangsa dan negara dan melibatkan diri dalam proses pembangunan bangsa dan negara secara lebih signifikan.

Keempat, gagasan ini sebagai implikasinya, merupakan manifesto intelektual dan politik Muhammadiyah. Berkenaan dengan manifesto intelektual, melalui gagasan ini, Muhammadiyah menegaskan bahwa Islam memiliki peran yang penting yang dapat dimainkan dalam bidang pembangunan nasional, dan sudah semestinya Muhammadiyah memainkan perannya tersebut. Sebagaimana yang diungkapkan Amin Abdullah bahwa, dinamisasi pemikiran Islam (Dar al-Ahd wa al-Shahadah) bertujuan untuk memertahankan relevansinya sesuai dengan ruang dan waktu (al-zaman wa al-makan), adaptabilitasnya melalui pembangunan sains dan teknologi (nazariyyah al-ma'rifah), dan orientasinya untuk menyelesaikan masalah-masalah kekinian terutama masalah 'dehumanisasi' ${ }^{58}$ Dalam rangka mewujudkan manifesto intelektual ini, Syamsuddin menekankan bahwa Muhammadiyah mengambil bagian dalam kontestasi interpretasi keagamaan (musabaqah al-tafsir), khususnya menyangkut "Pancasila" dan bentuk negara yang disepakati atasnya (Negara Pancasila). ${ }^{59}$

Akan tetapi, refleksi kritis Hajriyanto Thohari perlu kiranya didiskusikan di sini. Ia menyatakan bahwa pelbagai tantangan di masa mendatang adalah

57 Wawancara dengan Azaki Khoiruddin, Sekretaris Umum Pimpinan Pusat Ikatan Pelajar Muhammadiyah (IPM), sekaligus sebagai moderator grup WhatsApp Islam Berkemajuan. 28 Agustus 2018.

58 Amin Abdullah, "Agama dan Pancasila dalam Identitas Keindonesiaan," h. 80.

59 Din Syamsuddin, "Tafsir Islam atas Negara Pancasila," h. 162. 
menghadapi Islamisme dan menjamin proses demokratisasi yang substansial. ${ }^{60}$ Sebagai politisi, ia merenung secara mendalam bahwa situasi politik harian di Indonesia telah bergerak menuju demokrasi yang formal, yang menekankan mayoritarianisme dan dominasi para elit partai ('partitokrasi'), namun sayangnya bukan demokrasi yang substansial. Secara lebih khusus, partitokrasi sebenarnya berupaya mengorbankan idealisme demokrasi yang substansial di tangan oligarkisme. Tentulah, baik itu partitokrasi maupun oligarkisme bertentangan dengan konstitusi negara Indonesia (Undang-Undang Dasar 1945) dan juga Undang Undang Partai Politik yang menekankan prinsip-prinsip transparansi dan demokrasi. ${ }^{61}$

Jelas sekali, pendapat yang diajukan Abdullah dan Syamsuddin senada dengan refleksi Thohari, ketika ia menambahkan pelbagai realitas kompleks lainnya yang harus ditangani oleh Muhammadiyah. Berkaitan dengan realitas-realitas tersebut, Haedar Nashir secara optimis menyatakan bahwa Muhammadiyah harus menyelesaikannya dan akan senantiasa berkontribusi dalam rangka mewujudkan cita-cita bangsa dan negara di pelbagai bidang kehidupan yang ada. ${ }^{62}$ Syamsuddin tampaknya juga setuju dengan pendapat yang diajukan Nashir khususnya mengenai makna dar al-shahadah (negara persaksian) sebagai suatu dorongan untuk terlibat dalam pelbagai aksi partisipatoris dalam naungan spirit Islam Berkemajuan dalam rangka membangun Indonesia Berkemajuan. ${ }^{63}$ Sebagai bahan refleksi mengenai manifesto intelektual dan politik Muhammadiyah, Syamsuddin mengelaborasi bahwa Dar al-Ahd wa alShahadah mengandung dua jenis afirmasi bagi para aktivis Muhammadiyah: yang pertama adalah mengafirmasi diri mereka sebagai Muslim, sementara yang kedua adalah sebagai anak bangsa Indonesia. Kedua afirmasi tersebut memiliki kaitan yang erat dengan misi kekhalifahan (the Islamic caliphal [viceregency] mission) yang harus diwujudkan dalam konteks Indonesia (khalifatullah fi al-

60 Wawancara dengan Hajriyanto Thohari.

61 Thohari dengan penuh antusias menyatakan bahwa: "Dalam rangka menyelesaikan masalah-masalah demokrasi, partai-partai politik itu sendiri pertama-tama haruslah menginisiasi reformasi tradisi politik koruptif yang telah mereka praktekkan. Di samping itu, para kader Muhammadiyah harus juga didorong agar terlibat dalam proses reformasi tersebut. Namun ada syarat yang harus dipenuhi: Muhammadiyah harus secara lebih signifikan memproduksi kader yang mampu mewarnai tiga dimensi strategis: organisasi, ummah (di tengah masyarakat yang plural) dan kepemimpinan nasional." Wawancara dengan Hajriyanto Thohari.

62 Dalam membangun argumentasinya, Nashir merujuk kepada al-Qur'ān, "Wahai manusia, sesungguhnya kami menciptakan kalian dari seorang laki-laki dan perempuan, serta menjadikan kalian berbangsa-bangsa dan bersuku-suku supaya kalian saling mengenal. Sesungguhnya orang yang paling mulia di antara kalian di sisi Allah ialah orang yang paling takwa. Sesunggguhnya Allah Maha Mengetahui lagi Maha Mengenal" (Al-Hujurāt 49: 13). Haedar Nashir, "Muhammadiyah Membangun Integrasi Keislaman dan Kebangsaan Menuju Indonesia Berkemajuan," h. 29-30.

Din Syamsuddin, "Tafsir Islam atas Negara Pancasila," h. 162. 
ardina, Indonesia). ${ }^{64}$

Demikianlah keempat motif dan tujuan Muhammadiyah dalam mereformulasikan dan memproklamasikan gagasan Negara Pancasila sebagai Dar al-'Ahd wa al-Shahadah: bahwa hal tersebut merupakan (1) pedoman bagi para aktivis Muhammadiyah yang menjelaskan hubungan antara negara dan organisasi; (2) sebuah banteng pertahanan ideologis melawan segala bentuk Islamisme dan pelbagai ideologi dehumanistik lainnya; (3) sebuah instrumen harmonisasi politik antara negara dan Muhammadiyah; (4) dan juga manifesto intelektual dan politik yang mengafirmasi Muhammadiyah sebagai bagian dari Indonesia dan bahkan Indonesia itu sendiri.

\section{Tantangan dalam Implementasi Dar al-'Ahd wa al-Shahadah}

Muhammadiyah memiliki strategi-strategi dalam mendiseminasikan dan mengimplementasikan gagasan Negara Pancasila sebagai Dar al-Ahd wa alShahadah. Gagasan ini didiseminasikan dan disebarkan melalui pelbagai institusi, terutama amal usaha dan pelbagai aktivitas politiknya.

Pertama, penyebaran gagasan ini dilakukan melalui pelbagai institusinya, dengan cara mendistribusikannya kepada saluran-saluran organisatorisnya. Saluran utamanya adalah cabang-cabang di tingkat propinsi (Pimpinan Wilayah Muhammadiyah) dan daerah (Pimpinan Daerah Muhammadiyah) di seluruh Indonesia. Setelah proses legalisasi, ${ }^{65}$ dokumen resmi mengenai gagasan ini disebarkan ke pelbagai cabang-cabang tersebut. Dari pelbagai cabang ini, mereka akan menyebarkan salinannya ke cabang-cabang lokalnya (Pimpinan Daerah Muhammadiyah) dan cabang lokal yang lebih kecil lagi (Pimpinan Cabang Muhammadiyah dan Pimpinan Ranting Muhammadiyah). ${ }^{66}$ Dalam rangka mempercepat penyebaran ini, dokumen resmi tersebut juga disediakan versi digitalnya sehingga bisa diunduh secara online melalui website Muhammadiyah

64 Din Syamsuddin, "NKRI: Negara Perjanjian dan Kesaksian," h. 283.

65 "Legalisation" here refers to the process of Tanfidz Muhammadiyah.

66 Tingkatan-tingkatan organisatoris di dalam Muhammadiyah dimulai dari Pimpinan Pusat Muhammadiyah (PPM), lalu diikuti oleh cabang setingkat propinsi atau biasa disebut sebagai Pimpinan Wilayah Muhammadiyah (PWM). Tingkatan yang lebih kecil adalah cabang regional atau Pimpinan Daerah Muhammadiyah (PDM) di setiap distrik (kotamadya atau kabupaten), dan kemudian cabang yang disebut Pimpinan Cabang Muhammadiyah (PCM) di setiap kecamatan. Tingkat terkecilnya adalah Pimpinan Ranting Muhammadiyah (PRM) yang tersebar di setiap kelurahan dan desa. 
(www.muhammadiyah.or.id). ${ }^{67}$ Meskipun penggunaan internet sangatlah umum saat ini, tidak semua anggota Muhammadiyah mampu mengaksesnya. Hal ini disebabkan oleh karena segala keterbatasan yang ada mengenai teknologi yang mereka miliki, terutama mereka yang tinggal di daerah yang terluar dan terpencil misalnya di batas teritorial negara. ${ }^{68}$ Akan tetapi, para elit Muhammadiyah begitu cakap dan terampil dalam menyebarkan gagasan penting ini melalui media sosial dan juga telivisi. ${ }^{69}$ Beberapa intelektual di lingkungan Muhammadiyah memproduksi “opini” yang diterbitkan baik di koran-koran lokal maupun nasional, dan juga media online. Sementara itu organisasi intelektual (think thank) seperti MAARIF Institute mempublikasikan jurnal yang membahas tema spesifik mengenai gagasan ini. Sementara yang lain lagi, mempublikasikan buku-buku. ${ }^{70}$

Akan tetapi, apa yang telah dilakukan Muhammadiyah ini sebenarnya sangat menantang. Ketika perkembangan teknologi informasi sedemikian memberikan dampak yang besar, hal tersebut sayangnya tidak diikuti oleh kecakapan literasi kritis. Banyak orang, termasuk sebagian anggota Muhammadiyah belum mampu berpikir secara lebih kritis ketika mereka harus berhadapan dengan kabar bohong (hoax). Informasi yang salah (bohong) mempertajam minat mereka yang mengusung Islamisme, bahkan mereka mengungkapkannya dengan nada yang begitu subversif, dengan demikian memperumit tugas Muhammadiyah dalam mendiseminasikan gagasan Dar al-Ahd wa al-Shahadah. ${ }^{71}$ Salah satu jalan yang ditempuh Muhammadiyah di antara banyak jalan lainnya yang memungkinkan untuk mengatasi masalah ini, sebagaimana yang telah diupayakan oleh Majelis Pustaka dan Informasi Muhammadiyah, adalah mengembangkan

67 Lihat website resmi Muhammadiyah. It provides the documents that can be accessed instantly http://www. muhammadiyah.or.id/muhfile/download/muktamar47/Buku\%2010-Negara\%20Pancasila.pdf (Diunduh pada 6 September 2018).

68 M. Nurul Yamien, "Muhammadiyah dan Masyarakat Informasi," Republika, 3 Mei 2010.

69 Oleh karena perkembangan tekonologi, terutama internet dan media sosial, para elit Muhammadiyah memiliki kemampuan yang luar biasa dalam menyebarkan gagasan-gagasan mereka (dakwah), khususnya melalui WhatsApp, Facebook dan YouTube.

70 Salah satu sumber primer dari buku ini diterbitkan oleh Majelis Kader Pimpinan Pusat Muhammadiyah. Selain itu, topik khusus mengenai Dar al-'Ahd wa al-Shahadah juga didiskusikan di jurnal yang dikelola oleh MAARIF Institute.

71 Sebagian website yang menggunakan nama Muhammadiyah memiliki perspektif yang tampaknya konservatif dan bahkan mendorong ke arah radikalisasi. Secara lebih jauh, beberapa gagasan kelompok Islamis secara luas menyebar melalui media sosial seperti WhatsApp dan Facebook. Masalah ini pernah didiskusikan secara intensif di grup WhatsApp Muhammadiyah Berkemajuan (yang beranggotakan para elit Muhammadiyah) dan sebagai hasilnya, Muhammadiyah berupaya mengampanyekan pentingnya literasi kritis untuk para anggotanya. 
program jihad literasi. ${ }^{72}$ Tujuan utama dari jihd ini adalah hendak memperkuat kesadaran masyarakat agar supaya lebih bijaksana dan kritis dalam membaca dan mengevaluasi informasi yang ada.

Di samping itu, sebagai strategi diseminasi gagasan ini, Muhammadiyah memanfaatkan pelbagai amal usahanya seperti misalnya lembaga-lembaga pendidikannya (sekolah-sekolah dan universitas), lembaga-lembaga kesehatan (rumah sakit dan klinik) dan juga lembaga-lembaga filantropi (rumah terbuka, rumah yatim piatu dan panti jompo). Sejak 1912, dimulai dengan modernisasi sekolah-sekolah Islam yang diinisiasi oleh KH. Ahmad Dahlan, ${ }^{73}$ Muhammadiyah secara khusus memainkan peran kependidikan yang begitu penting, yang memproduksi banyak tokoh nasional terkemuka. Saat ini, kontribusinya meningkat oleh karena meningkatnya jumlah lembaga pendidikan yang dimilikinya; sebagaimana yang telah ditunjukkan oleh database resmi organisasi, Muhammadiyah memiliki 4786 sekolah dan 171 universitas yang tersebar di seluruh pelosok negeri. ${ }^{74}$ Di samping itu, lembaga-lembaga lain yang dimilikinya juga berkontribusi pada pembangunan Indonesia. ${ }^{75}$ Para elit Muhammadiyah, dalam konteks ini, mengklaim bahwa segala kontribusi yang telah diupayakan tersebut dapat dipertimbangkan sebagai implementasi dari gagasan dar al-shahadah. ${ }^{76}$

Secara ideal, pelbagai institusi ini akan memberikan pengaruh yang signifikan dalam memperkuat kesadaran terhadap pentingnya gagasan ini. Akan tetapi, tidak semua guru dan dosen dari lembaga-lembaga pendidikan Muhammadiyah setuju dengan konsep tersebut. ${ }^{77} \mathrm{Hal}$ ini, kenyataannya, menjadi masalah yang besar bagi Muhammadiyah. Tidak dapat dipungkiri bahwa sebagian kalangan Muslim masih meyakini pentingnya gagasan dar al-Islam dari pada dar al-Ahd wa

72 Program ini bukan hanya penting untuk mengentaskan iliterasi, tetapi juga mendorong yang lain untuk membangun kebiasaan membaca dan berpikir kritis, atau sekurang-kurangnya mampu mempertimbangkan validitas informasi yang tersebar di media sosial.

73 Hyung-Jun Kim, Reformist Muslim in a Yogyakarta Village: The Islamic Transformation of Contemporary Socio-Religious Life, (Canberra: ANU E Press, 2007), h. 53-55; Alfian, Politik Kaum Modernis, Perlawanan Muhammadiyah terhadap Kolonialisme Belanda, h. 168-169; Mitsuo Nakamura, The Crescent Arises over the Banyan Tree: A Study of the Muhammadiyah Movement in a Central Javanese Town, c.1910-2010, h. 93-102.

74 Pimpinan Pusat Muhammadiyah, "Data Amal Usaha Muhammadiyah," dlm. Muhammadiyah http://www. muhammadiyah.or.id/content-8-det-amal-usaha.html (Diunduh 6 September 2018).

75 Hilman Latief, Islamic Charities and Social Activism: Welfare, Dakwah and Politics in Indonesia; Amelia Fauzia, Faith and the State: A History of Islamic Philanthropy in Indonesia.

76 Haedar Nashir, "Muhammadiyah Membangun Integrasi Keislaman dan Kebangsaan Menuju Indonesia Berkemajuan," h. 32.

77 Wawancara dengan Azaki Khoiruddin, 30 Agustus 2018. 
al-Shahadah. Selain itu, sebagian aktivis Muhammadiyah, di saat yang sama juga mendukung pelbagai gagasan dan aktivitas HTI, JAT, JAD, dan yang lainnya. ${ }^{78}$

Namun secara lebih jauh, Muhammadiyah tetap berharap dalam mendiseminasikan gagasan tersebut melalui langkah dan strategi 'high politics'nya. Sebagai contoh, ketika Muhammadiyah dengan tegas menyatakan bahwa dirinya bukanlah partai politik dan tidak bermain dalam ranah politik praktis (realpolitik), Muhammadiyah mengklaim bahwa lebih memilih untuk berpartisipasi dalam proses demokratisasi yang bersifat substansial. ${ }^{79}$ Dengan kata lain, Muhammadiyah bersikukuh mempertahankan bahwa atas apa yang dilakukannya merupakan hal yang berbeda dari segala praktik realpolitik, yang semata-mata hanya bertujuan untuk meraih kursi kekuasaan. ${ }^{80}$ Muhammadiyah lebih menghendaki dirinya sebagai sebuah organisasi masyarakat sipil, yang bersfungsi sebagai penyeimbang kekuatan antara penguasa dan rakyat atau antara kebijakan negara dan aspirasi warga negara. ${ }^{81}$ Sebagaimana yang telah dungkapkan oleh Amin Abdullah, Muhammadiyah memiliki peran ganda dalam mengontrol dan mentransformasi dalam pengertian mengimplementasikan nilai-nilai kebangsaan yang luhur dan penuh kebajikan. ${ }^{82}$

Dalam menjelaskan pelbagai strategi, motif dan tujuannya, sebagaimana yang telah tertulis di dalam dokumen resminya, Muhammadiyah menghendaki bahwa, dalam mentrasformasikan Negara Pancasila agar supaya menjadi Indonesia yang Berkemajuan, Muhammadiyah mengundang seluruh elit bangsa ini untuk senantiasa mempertahankan moralitasnya yang baik secara konsisten, memenuhi mandate rakyat, memperjuangkan cita-cita rakyat daripada memenuhi kepentingannya sendiri, atau kelompok dan partainya sendiri. Muhammadiyah sangat mendorong pemerintah untuk membangun bangsa dan

78 Wawancara dengan Zuly Qodir, 30 Agustus 2018. Selain itu, Pradana Boy ZTF menyoroti adanya fenomena radikalisasi di dalam Muhammadiyah. Pradana Boy ZTF., "Another Face of Puritan Islam: Muhammadiyah and Radicalism among the Youth,"the Paper presented in the International Research Conference on Muhammadiyah," (Malang: The University of Muhammadiyah Malang, 2012), h. 379-416. Lihat juga Zuly Qodir, "Reorientasi Tajdid Pemikiran dalam Muhammadiyah," Muhammadiyah Studies: Reorientasi Gerakan dan Pemikiran Memasuki Abad Kedua, (Yogyakarta: Kanisius, 2010), h. 39-72.

79 Syarifuddin Jurdi (eds.), 1 Abad Muhammadiyah: Gagasan Pembaruan Sosial Keagamaan, (Jakarta: Kompas, 2010), h. 305; Hajriyanto Thohari, "la Bukan Muadzin Lagi," dlm. Muhammad Najib et.al., Suara Amien Rais, Suara Rakyat, (Jakarta, Gema Insani Press, 1999), h. 103-106; Amien Rais, Moralitas Politik Muhammadiyah, (Yogyakarta: Dinamika, 1995), h. 43-44.

80 Haedar Nashir, Revitalisasi Gerakan Muhammadiyah, (Yogyakarta: Bigraf Publishing, 1999), h. 197.

81 Wawancara dengan Abd. Rohim Ghazali, Sekretaris Lembaga Hikmah dan Kebijakan Publik Muhammadiyah, 30 Agustus 2018.

82 Amin Abdullah, "Muhammadiyah's Experience in Promoting Civil Society on the Eve of the 21st Century," dlm. Mitsuo Nakamura, Sharon Siddique and Omar Farouk Bajunid, Islam and Civil Society in Southeast Asia, (Singapore: ISEAS, 2001), h. 43-56. 
negeri dengan sepenuhnya memperhatikan nilai-nilai keadilan, kejujuran dan kebangsaan, termasuk pula agar tidak melakukan penyalahgunaan kekuasaan. Oleh karena itulah, maka Muhammadiyah menekankan bahwa Indonesia akan dibangun berdasarkan sendi-sendi nilai berkemajuan, pencerahan dan kenabian sebagaimana yang telah diinspirasikan oleh prinsip-prinsip luhur dan Islami Pancasila. ${ }^{83}$

Akan tetapi realitas yang dihadapi agaknya memang berbeda. Beberapa aktivis yang ada di saat yang sama juga merupakan politisi, yang tersebar di pelbagai partai politik dan dengan demikian memiliki peran yang vital dalam proses kontestasi realpolitik. Dalam momen transisi demokrasi 1998, Amien Rais sebagai Ketua Pimpinan Pusat Muhammadiyah pada saat itu, memimpin para aktivis dan mahasiswa untuk menggulingkan rezim Presiden Soeharto. Kontribusinya yang sungguh luar biasa untuk bangsa ini, menuai pujian dari kalangan sarjana dan intelektual, dan bahkan ia dianugerahi gelar yang terhormat, yakni Bapak Reformasi. ${ }^{84}$ Pasca era otoritarian Soeharto, ${ }^{85}$ ia mendirikan Partai Amanat National (PAN) dan menduduki jabatan sebagai Ketua Majelis Permusyawaratan Rakyat (MPR). Dengan posisi yang strategis tersebut, ia menginisiasi proses amandemen konstitusi (Undang-Undang Dasar 1945) yang meratifikasi keseluruhan pasal Deklarasi Universal Hak Asasi Manusia (Universal Declaration of Human Rights/UDHR) ke dalam konstitusi negara kita. ${ }^{86}$

Ada beberapa tokoh lain yang perlu dicatat di sini. Imam Addaruqutni, sebagai contoh, mendirikan Partai Matahari Bangsa di tahun 2006, meskipun partai ini gagal mempertahankan dirinya di medan laga politik yang sangat kompetitif. Ahmad Rofiq mendirikan Partai Nasional Demokrat (Nasdem) di tahun 2011 yang kemudian diambil alih oleh seorang konglomerat, Surya Paloh. Di tahun 2015, Rofiq mendirikan Partai Persatuan Indonesia (Perindo). Sementara itu, aktivis dan politisi Muhammadiyah yang lebih muda, Raja Juli Antoni, menginisiasi Partai

83 Pimpinan Pusat Muhammadiyah, Negara Pancasila sebagai Darul Ahdi wa Syahadah, h. 20-21.

84 Muhammad Najib dan KS. Himmaty, Amien Rais dari Yogya ke Bina Graha, (Jakarta: Gema Insani Press, 1999).

85 Denny JA., Melewati Perubahan: Sebuah Catatan Atas Transisi Demokrasi Indonesia, (Yogyakarta: LKIS, 2006), h. 283; Emha Ainun Nadjib, Saat-saat Terakhir Bersama Soeharto: 2,5 Jam di Istana, (Yogyakarta: Bentang, 2016), h. 62.

86 Denny Indrayana, Indonesian Constitutional Reform 1999-2002: An Evaluation of Constitution Making in Transition, (Jakarta: Kompas, 2008), h. 316; Lihat secara lebih jauh Donald L. Horowitz, "A Game of Inches," Constitutional Change and Democracy in Indonesia, (Cambridge: Cambridge University Press, 2013), h. 89-123. 
Solidaritas Indonesia (PSI) di tahun 2014 yang dipersiapkan untuk bertarung pada Pemilihan Umum (Pemilu) tahun 2019.

Fenomena mengenai politik praktis di antara para aktivis Muhammadiyah menunjukkan bahwa sebenarnya posisi Muhammadiyah bersifat ambivalen. Dalam pengertian, mengafirmasi posisi moral tertentu yang dianggap setingkat lebih tinggi di atas perkara politik, namun juga terlibat dalam permainan realpolitik. Kendati demikian, menurut Hajriyanto Thohari, seorang aktivis Muhammadiyah dan Wakil Ketua MPR dari tahun 2009 sampai 2014, bahwa kenyataan mengenai ambivalensi ini dapat memberikan sumbangsih yang bermakna bagi masyarakat. ${ }^{87}$ Ia mengklaim bahwa Muhammadiyah harus mendorong para kadernya yang mampu berpartisipasi di dalam pelbagai partai politik untuk membawa serta nilainilai moral dan keagamaan dalam proses formulasi kebijakan-kebijakan politik. Dengan demikian, itu semua dapat memastikan bahwa mereka sebenarnya sangat pro-keadilan dan kemanusiaan. ${ }^{88}$ Tentu aja, meskipun gagasan keterlibatan moral ini tidak selalu diikuti dengan baik, terutama oleh karena mereka lebih dipengaruhi oleh tuntutan politik yang berlandas kepada kalkulasi rasional, hal tersebut masihlah menjadi dasar-dasar yang penting sekali, yang menentukan perilaku politik mereka. ${ }^{89}$ Satu hal mengenai hal ini yang sangat memungkinkan untuk dilakukan adalah memprioritaskan proses politik yang bersifat substantif, atau dengan pengertian lain, tidak sesederhana melaksanakan demokrasi yang formal atau semu (façade democracy). Muhammadiyah berusaha mewujudkan jalan moderat ini, salah satunya adalah melalui program Jihad Konstitusi yang meninjau kembali hukum dan perundang-undangan yang dianggap bertentangan dengan kepentingan umum, dan prinsip-prinsip keadilan dan kemanusiaan, serta dengan demikian, yang bertentangan dengan konstitusi. ${ }^{90}$

BagiMuhammadiyah, ada pelbagaitantangandalam rangka mengimplementasikan gagasan Negara Pancasila sebagai Dar al-Ahd wa al-Shahadah. Hal ini termasuk di antaranya adalah tumbuh-suburnya ideologi Islamisme di dalam gerakan

87 Wawancara dengan Hajriyanto Thohari.

88 Ibid.,

89 Wawancara dengan Abd. Rohim Gazali.

90 Lihat Stefanus Hendrianto, Law and Politics of Constitutional Courts: Indonesia and the Search for Judicial Heroes, (Oxon; New York: Routledge, 2018), h. 206, 221. 
Muhammadiyah itu sendiri, munculnya populisme Islamis, ${ }^{91}$ dan masalah-masalah kompleks yang dihadapi oleh negara ini seperti misalnya korupsi, ketidakadilan, pengaruh-pengaruh negatif dari adanya korporasi-korporasi neoliberal, disparitas sosial, kemiskinan dan tren partitokrasi juga oligarkisme politik.

Tantangan pertama mereka adalah kebangkitan Islamisme dari dalam. Sebagaimana yang telah disinggung sebelumnya, ideologi penegasian religius atau takfiriyyah secara massif tumbuh subur dan menginfiltrasi Muhammadiyah. Di satu sisi, organisasi ini bersifat puritan oleh karena memang dalam urusan keagamaan sepenuhnya merujuk kepada sumber-sumber utama Islam seperti misalnya al-Qur'an dan Sunnah. Di sisi lain, Muhammadiyah juga setuju dalam hal tertentu dengan ideologi Wahhabisme. Kendati demikian, hal tersebut bukanlah faktor utama yang menentukan merebaknya Islamisme di lingkungan Muhammadiyah. Secara lebih penting, yang begitu menentukan adalah koneksi kultural dan politik dari gerakan-gerakan Islam transnasional yang tampaknya lebih bersifat resisten terhadap modernisasi. Sementara itu, hal-hal lain yang perlu dipertimbangkan adalah masalah sosial, ekonomi, politik dan kebudayaan yang kompleks di Indonesia, yang dipahami sebagai faktor penentu yang secara signifikan mempengaruhi adanya ketidakpercayaan terhadap negara dan pemerintah, termasuk pula mempengaruhi timbulnya wacana alternatif yang mengklaim bahwa sistem dan praktik politik di Indonesia tidaklah Islami. Akumulasi dari seluruh faktor ini berdampak terhadap konstruksi ideologis sebagian kaum Muslim, khususnya di lingkungan aktivis Muhammadiyah, dan juga mendorong minat mereka agar bergabung dengan kelompok-kelompok Islam lainnya yang lebih konservatif dan bahkan radikal.92 Dengan demikian, sudah tidak mengejutkan lagi apabila sebagian aktivis Muhammadiyah lantas kemudian bergabung dengan HTI atau bahkan organisasi-organisasi Salafi yang jihadis. ${ }^{93}$

Di samping itu, munculnya populisme Islamis ke permukaan, juga merupakan tantangan besar bagi Muhammadiyah. Setahun setelah adanya kampanye mengenai Dar al-Ahd wa al-Shahadah (2017), Muhammadiyah harus berdiri

91 Populisme Islamis adalah populisme politik yang melibatkan kelompok Islamis sebagai agensi mobilisasi. Konsep ini merujuk kepada Jenny B. White, Islamist Mobilization in Turkey: A Study in Vernacular Politics, (Washington, DC: The University of Washington Press, 2002); Maidul Islam, Jamaat-e-Islami in Contemporary India and Bangladesh, (Delhi, India: Cambridge University Press, 2015). Sementara itu, sarjana lainnya seperti misalnya Vedi R. Hadiz menggunakan istilah 'Islamic populism' atau populisme Islami ketimbang populisme Islamis. Lihat Vedi R. Hadiz, Islamic Populism in Indonesia and the Middle East, (Cambridge: Cambridge University Press, 2016).

92 Wawancara dengan seorang aktivis Muhammadiyah (yang memohon anonimitas bagi identitasnya), 30 Agustus 2018. Lihat juga Din Syamsuddin, "Tafsir Islam atas Negara Pancasila," $\mathrm{h} 160$.

93 Wawancara dengan Zuly Qodir. 
berhadapan langsung dengan perkembangan yang begitu pesat dari pada gerakan rakyat populis yang sedang marah dan bahkan berdemonstrasi sebagaimana yang tampak pada gerakan massa Aksi Bela Islam 212 and $411 .{ }^{94}$ Upaya meluapkan kemarahan, terutama di lingkaran kaum Muslim konservatif, dilakukan oleh karena mereka memandang bahwa di negeri ini keadilan dan kesejahteraan tidak terpenuhi dengan baik, dan seringkali para elit politik justru seringkali berusaha memanipulasi isu tersebut untuk kepentingan-kepentingannya sendiri. ${ }^{95}$ Bagi Muhammadiyah, konsekuensinya, harus menghadapi kesulitan yang berlipat ganda, yakni bahwa gagasannya yang hendak memperkuat hubungan politik dengan penguasa (Muhammadiyah Berkemajuan untuk Indonesia Berkemajuan) menjadi semakin berat untuk diterapkan dengan baik; dan sebagian aktivis Muhammadiyah yang bergabung dengan gerakan-gerakan populisme Islamis dalam rangka menjatuhkan kritik terhadap pemerintah dianggapnya sebagai hal yang selaras dengan misi Islam Berkemajuan (menurut versi mereka sendiri). ${ }^{96}$ Sebagian aktivis Muhammadiyah merupakan aktoraktor politik praktis yang turut menginstrumentalisasikan agama untuk kepentingan politik, sementara sebagian yang lain meyakini bahwa gerakan massa populis adalah hal yang benar-benar murni merupakan tuntutan agama, terutama bagian dari amar ma'ruf nahi munkar (berbuat kebajikan dan mencegah kemunkaran). Tidak dapat dipungkiri pula, sebagai konsekuensi dari adanya hal ini adalah menyebabkan retaknya hubungan di antara para aktivis Muhammadiyah dengan pelbagai pijakan ideologis dan teologis yang dimiliki. Pada akhirnya, hal tersebut menimbulkan fragmentasi dan tidak menutup kemungkinan, akan menimbulkan konflik di kemudian hari.

94 Greg Fealy, "Bigger than Ahok: Explaining the 2 December Mass Rally," Indonesia at Melbourne, (7 Desember 2016) http://indonesiaatmelbourne.unimelb.edu.au/bigger-than-ahok-explaining-jakartas-2-december-mass-rally/ (Diunduh pada 31 Augustus 2018).

95 Richard Robison dan Vedi R. Hadiz, "Indonesia: A Tale of Misplaced Expectations," The Pacific Review, Vol. 30, No. 6 (2017), h. 895-909; Marcus Mietzner dan Burhanuddin Muhtadi, "Explaining the 2016 Islamist Mobilisation in Indonesia: Religious Intolerance, Militant Groups and the Politics of Accommodation," Asian Studies Review, Vol. 42, Issue 3 (2018), h. 479-497; Marcus Mietzner, "Indonesia's Growing Islamist Populism," Carnegie Council for Ethics in International Affairs (19 Desember 2016), https://www.carnegiecouncil.org/studio/ multimedia/20161219-indonesias-growing-islamist-populism (Diunduh 30 Agustus 2018); Luthfi Assyaukanie, "Unholy Alliance: Ultra-Conservatsm and Political Pragmatism in Indonesia," Thinking ASEAN Issue (19 Januari 2017) http://www.thcasean.org/read/articles/327/Unholy-Alliance-Ultra-Conservatism-and-Political-Pragmatismin-Indonesia (Diunduh 30 Agustus 2018).

96 Di dalam grup WhatsApp Indonesia Berkemajuan, para aktivis Muhammadiyah menunjukkan dukungannya bagi adanya populisme Islamis melalui pelbagai cara, mengklaim bahwa mereka hendak bergabung pada gerakan demonstrasi massa Islamis, oleh karena hal tersebut dianggap selaras dengan visi Islam Berkemajuan (menurut versi yang mereka kehendaki sendiri). 


\section{Kesimpulan}

Sudah sejak lama Muhammadiyah mempromosikan gagasan Islam Berkemajuan, bahkan secara historis, hal ini berlaku sejak masa-masa pendiriannya. Dalam mempromosikan Islam Berkemajuan, organisasi Muslim modernis terbesar di Indonesia ini memahami bahwa Islam merupakan agama yang berorientasi ke depan, yang secara dinamis mampu menyelesaikan masalah-masalah kekinian yang pelik dan tidak mudah dalam pelbagai bidang kehidupan.

Dalam konteks menghadapi masalah-masalah yang ada beserta kompleksitasnya, Muhammadiyah mengontekstualisasikan gagasan Islam Berkemajuan tersebut dalam bentuk gagasan Negara Pancasila sebagai Dar al-Ahd wa al-Shahadah. Dalam hal ini, Indonesia dipahami sebagai negara perjanjian, kesepakatan atau konsensus (dar al-ahd) dan negara persaksian (al-shahadah). Artinya, Muhammadiyah berargumentasi bahwa Indonesia ini sudah final karena telah disepakati oleh para pendiri bangsa. Konsekuensinya, Indonesia tidak dipahami sebagai negara Islam terlebih sebagai negara kafir yang patut diperangi. Lebih dari itu, Muhammadiyah juga memandang bahwa segenap orang bangsa, kaum Muslim dan secara khusus warga Muhammadiyah, harus terlibat secara aktif dan partisipatoris dalam proses pembangunan bangsa dan negara, yang pada akhirnya akan menyaksikan terwujudnya peradaban kemanusiaan yang luhur di Indonesia. Hal ini membawa implikasi konseptual bahwa Muhammadiyah bukanlah sekedar bagian dari Indonesia, tetapi juga Indonesia itu sendiri. Dar al-Ahd wa al-Shahadah itu sendiri bertujuan memberikan pedoman bagi para aktivis Muhammadiyah mengenai hubungan negara dan organisasi, sebagai fondasi pertahanan ideologis, sebagai alat harmonisasi politik, dan manifestasi intelektual dan politik yang menekankan pentingnya nasionalisme.

Dalam mengimplementasikan gagasan tersebut, Muhammadiyah harus berhadapan dengan masalah yang tidak sederhana. Hal ini, termasuk di antaranya adalah tumbuh-suburnya ideologi Islamisme di dalam gerakan Muhammadiyah itu sendiri, munculnya populisme Islamis, dan masalah-masalah kompleks yang dihadapi oleh negara ini seperti misalnya korupsi, ketidakadilan, pengaruhpengaruh negatif dari adanya korporasi-korporasi neoliberal, disparitas sosial, kemiskinan dan tren partitokrasi juga oligarkisme politik.

Pada akhirnya, artikel ini secara argumentatif menyatakan bahwa, Muhammadiyah secara khusus berupaya meredam laju gerakan Islamisme (termasuk populisme Islamis sebagai akibat dari faktor merebaknya Islamisme) di Indonesia, dengan mengampanyekan gagasan alternatif, yakni Negara 
Pancasila sebagai Dar al-Ahd wa al-Shahadah (negara perjanjian dan persaksian). Akan tetapi, secara implementatif, Muhammadiyah harus menghadapi tantangan-tantangan yang tidak mudah, seperti misalnya adanya sebagian aktivis Muhammadiyah sendiri yang cenderung konservatif, adanya faktor eksternal yang memungkinkan infiltrasi ideologis (khususnya Islamisme) sehingga menyebabkan pemisahan diri dan pengerasan sikap keberagamaan, dan adanya kontestasi politik praktis musiman yang melibatkan pelbagai instrumentalisasi agama untuk kepentingan politik kekuasaan (populisme Islamis). Demikianlah, keberhasilan mengenai gagasan Dar al-Ahd wa al-Shahadah secara praktis sebenarnya tergantung kepada para aktivis Muhammadiyah itu sendiri. Hal ini, tentu sangat terbuka untuk diamati hingga saat ini.[] 


\section{Daftar Pustaka}

Abdullah, Amin. "Agama dan Pancasila dalam Identitas Keindonesiaan,” dlm Muamaroh dan Benni Setiawan, eds. Negara Pancasila, Darul 'Ahdi Wasy-Syahadah: Perspektif Teologis dan Ideologis. Yogyakarta: Majelis Pendidikan Kader Pimpinan Pusat Muhammadiyah. 2017: 79-103.

Abdullah, Amin. "Muhammadiyah's Experience in Promoting Civil Society on the Eve of the 21st Century," dlm. Mitsuo Nakamura, Sharon Siddique and Omar Farouk Bajunid, Islam and Civil Society in Southeast Asia. Singapore: ISEAS. 2001: 43-56.

Abdurrahman, Asjmuni. Manhaj Tarjih Muhammadiyah: Metodologi dan Aplikasi. Yogyakarta: Pustaka Pelajar, 2002.

Abdurrahman, Moeslim. Islam sebagai Kritik Sosial. Jakarta: Erlangga, 2003.

Alfian. Politik Kaum Modernis, Perlawanan Muhammadiyah terhadap Kolonialisme Belanda. Jakarta: Al-Wasat, 2010.

Amar, Faozan dan Dinan Hasbudin Apip. "Darul-Ahdi Wasy-Syahadah: Makna dan Implementasi,” dlm. Faozan Amar et.al. eds. Darul-Ahdi Wasy-Syahadah: Konteks, Makna dan Aktualisasi untuk Indonesia Berkemajuan. Yogyakarta: Majelis Pendidikan Kader Pimpinan Pusat Muhammadiyah, 2017.

Assyaukanie, Luthfi. "Unholy Alliance: Ultra-Conservatism and Political Pragmatism in Indonesia," Thinking ASEAN Issue. 19 Januari 19 2017. http://www.thcasean.org/read/articles/327/Unholy-AllianceUltra-Conservatism-and-Political-Pragmatism-in-Indonesia Diunduh 30 Agustus 2018.

Baidhawy, Zakiyuddin. "The Muhammadiyah's Promotion of Moderation," The American Journal of Islamic Social Sciences 32.3 (2015): 69-91.

Baidhawy, Zakiyuddin, 2016. "Pancasila Tauhid Sosial dalam Kehidupan Berbangsa dan Bernegara,” MAARIF, 11. 1 (2016): 41-78.

Barton, Greg. "Indonesia,” dlm. Barry Rubin, ed. Guide to Islamist Movements. New York: ME Sharpe, 2010: 133-148. 
Barton, Greg. Indonesia's Struggle, Jamaah Islamiyah and the Soul of Islam. Sydney: University of New South Wales Press, 2004.

Solahudin. The Roots of Terrorism in Indonesia: From Darul Islam to Jema'ah Islamiyah, translated by Dave McRae. Sydney: UNSW Press, 2013.

Bayat, Asef, ed. Post-Islamism: The Changing Faces of Political Islam. Oxford: Oxford University Press, 2013.

Beck, Herman L. "The Borderline between Muslim Fundamentalism and Muslim Modernism: An Indonesian Example,” dlm. Jan Willem van Henten dan Anton Houtepen, eds. Religious Identity and the Invention of Tradition. Assen, the Netherland: Royal Van Gorcum, 2001. 279-291.

Boy ZTF., Pradana. In Defence of Pure Islam: Conservative-Progressive Debate within Muhammadiyah. Thesis, The Australian National University, 2007.

Boy ZTF., Pradana. Fatwa in Indonesia: An Analysis of Dominant Legal Ideas and Mode of Thought of Fatwa Making Agencies and Their Implications in the Post-New Order Period. Amsterdam: Amsterdam University Press, 2018.

Bsoul, Labeeb Ahmed. "Theory of International Relations in Islam,” Digest of Middle East Studies 16 (2007): 71-96.

Burhani, Ahmad Najib. "Absennya Muhammadiyah dalam Kabinet Kerja Jokowi-JK,” Koran SINDO. 13 November 2014.

Burhani, Ahmad Najib. "The Ideological Shift of Muhammadiyah from Cultural into Puritanical Tendency in 1930s,” Jurnal Masyarakat dan Budaya 3. 1 (2006): 1-22.

Burhani, Ahmad Najib. "Liberal and Conservative Discourses in the Muhammadiyah: The Struggle for the Face of Reformist Islam in Indonesia," dlm. Martin van Bruinessen, ed. Contemporary Developments in Indonesian Islam: Explaining the "Conservative Turn". Singapore: ISEAS, 2013. 105-144.

Burhani, Ahmad Najib. Muhammadiyah Berkemajuan: Pergeseran dari Puritanisme ke Kosmopolitanisme. Bandung: Mizan, 2016.

Burhani, Ahmad Najib. Muhammadiyah Jawa. Yogyakarta: Suara 
Muhammadiyah, 2016.

Darban, Ahmad Adaby. Sejarah Kauman: Menguak Identitas Kampung Muhammadiyah. Yogyakarta: Suara Muhammadiyah, 2010.

Denny JA. Melewati Perubahan: Sebuah Catatan Atas Transisi Demokrasi Indonesia. Yogyakarta: LKIS, 2006.

Fachrudin. Boeah Fikiran Kijai H.A. Dachlan. Jakarta: Global Base Review STIEAD Press, 2015.

Fauzia, Amelia. Faith and the State: A History of Islamic Philanthropy in Indonesia. Leiden: Brill, 2013.

Fealy, Greg. "Islamisation and Politics in Southeast Asia: The Contrasting Cases of Malaysia and Indonesia," dlm. Nelly Lahoud dan Anthony H. Johns, eds. Islam in World Politics. London; New York: Routledge, 2005: 152-169

Fealy, Greg. "Bigger than Ahok: Explaining the 2 December Mass Rally," Indonesia atMelbourne. 7 Desember 2016. http://indonesiaatmelbourne. unimelb.edu.au/bigger-than-ahok-explaining-jakartas-2-december-massrally/ Diunduh pada 31 Agustus 2018.

Ford, Christopher A. "Siyar-ization and Its Discontents: International Law and Islam's Constitutional Crisis," dlm. Mashood A. Baderin, ed. International Law and Islamic Law. Aldershot, Hampshire, England; Burlington, Vermont: Ashgate, 2008: 19-53.

Hadiz, Vedi R. Islamic Populism in Indonesia and the Middle East. Cambridge: Cambridge University Press, 2016.

Hakiem, Lukman, ed. Dari Muhammadiyah untuk Indonesia: Pemikiran dan Kiprah Ki Bagus Hadikusumo, Mr Kasman Singodimedjo, dan KH Abdul Kahar Mudzakkir. Yogyakarta: Pimpinan Pusat Muhammadiyah, 2013.

Hakim, Sudarnoto Abdul. "Muhammadiyah dan Kebudayaan Kita," dlm. Alpha Amirrachman, Andar Nubowo dan Azaki Khoiruddin, eds. Islam Berkemajuan untuk Peradaban Dunia: Refleksi dan Agenda Muhammadiyah ke Depan. Bandung: Mizan, 2015: 50-67.

Hendrianto, Stefanus. Law and Politics of Constitutional Courts: Indonesia 
and the Search for Judicial Heroes. Oxon; New York: Routledge, 2018.

Horowitz, Donald L. Constitutional Change and Democracy in Indonesia. Cambridge: Cambridge University Press, 2013.

Hosen, Nadirsyah. Shari'a \& Constitutional Reform in Indonesia. Singapore: ISEAS, 2007.

Analcık, Halil. "D $\llbracket r$ al-AAhd," in P. Bearman, Th. Bianquis, C.E. Bosworth, E. van Donzel, dan W.P. Heinrichs, eds. Encyclopaedia of Islam, Second Edition. 3 September 2018. http://dx.doi.org/10.1163/1573-3912_ islam_SIM_1698 Diunduh pada 6 September 2018.

Indrayana, Denny. Indonesian Constitutional Reform 1999-2002: An Evaluation of Constitution Making in Transition. Jakarta: Kompas, 2008.

Islam, Maidul. Jamaat-e-Islami in Contemporary India and Bangladesh. Delhi, India: Cambridge University Press, 2015.

Jurdi, Syarifuddin, eds. 1 Abad Muhammadiyah: Gagasan Pembaruan Sosial Keagamaan. Jakarta: Kompas, 2010.

Jurdi, Syarifuddin. Muhammadiyah dalam Dinamika Politik Indonesia 19662006. Yogyakarta: Pustaka Pelajar, 2010.

Kamali, Mohammad Hashim. The Middle Path of Moderation in Islam: The Qur'anic Principle of Wasatiyyah. Oxford; New York: Oxford University Press, 2015.

Khadduri, Majid. "The Islamic Theory of International Relations and Its Contemporary Relevance," dlm. Harris Proctor, ed. Islam and International Relations. London; Dunmow: Pall Mall Press, 1965: 24-39.

Khadduri, Majid. "Translators's Introduction," dlm. Muhammed ibn al-Hasan al-Shaybani, The Islamic Law of Nations, diterjemahkan Majid Khadduri. Baltimore, Maryland: Johns Hopkins University Press, 1966.

Khadduri, Majid. "Islam and the Modern Law of Nations," dlm. Mashood A. Baderin, ed. International Law and Islamic Law. Aldershot, Hampshire, England; Burlington, Vermont: Ashgate, 2008: 3-17.

Khoirudin, Azaki. Teologi al'Ashr: Etos dan Ajaran KHA Dahlan yang Terlupakan. Yogyakarta: Suara Muhammadiyah, 2015. 
Kim, Hyung-Jun. Reformist Muslim in a Yogyakarta Village: The Islamic Transformation of Contemporary Socio-Religious Life. Canberra: ANU E Press, 2007.

Kuntowijoyo. Muslim Tanpa Masjid: Esai-esai Agama, Budaya dan Politik dalam Bingkai Strukturalisme Transendental. Bandung: Mizan, 2001.

Kurzman, Charles, ed. Modernist Islam 1840-1940, A Sourcebook. Oxford; New York: Oxford University Press, 2002.

Latief, Hilman. Islamic Charities and Social Activism: Welfare, Dakwah and Politics in Indonesia. Dissertation, University of Utrecht, 2012.

Maarif, Ahmad Syafii. Islam dalam Bingkai Keindonesiaan dan Kemanusiaan: Sebuah Refleksi Sejarah. Bandung: Mizan, 2009.

Maarif, Ahmad Syafii. "Antara Pembantu dan Penentu," in Abdul Mu'ti et.al. eds. Kosmopolitanisme Islam Berkemajuan. Surakarta: Muhammadiyah University Press, 2015: 427-438.

Madjid, Nurcholish. Islam, Kemodernan dan Keindonesiaan. Bandung: Mizan, 2008.

Masduqi, Irwan. Berislam secara Toleran: Teologi Kerukunan Umat Beragama. Bandung: Mizan, 2011.

Mietzner, Marcus dan Burhanuddin Muhtadi. "Explaining the 2016 Islamist Mobilisation in Indonesia: Religious Intolerance, Militant Groups and the Politics of Accommodation," Asian Studies Review, 42.3 (2018): 479 . 497.

Mietzner, Marcus. "Indonesia's Growing Islamist Populism," Carnegie Council for Ethics in International Affairs. 19 December 2016 https://www. carnegiecouncil.org/studio/multimedia/20161219-indonesias-growingislamist-populism Diunduh pada 30 Agustus 2018.

Mu'ti, Abdul, et.al. eds. Kosmopolitanisme Islam Berkemajuan. Surakarta: Muhammadiyah University Press, 2015.

Mulkhan, Abdul Munir. Marhaenis Muhammadiyah. Yogyakarta: Galang Press, 2010.

Nadjib, Emha Ainun. Saat-saat Terakhir Bersama Soeharto: 2,5 Jam di Istana. 
Yogyakarta: Bentang, 2016.

Najib, Muhammad dan KS. Himmaty. Amien Rais dari Yogya ke Bina Graha. Jakarta: Gema Insani Press, 1999.

Nakamura, Mitsuo. The Crescent Arises over the Banyan Tree: A Study of the Muhammadiyah Movement in a Central Javanese Town, c.1910-2010, 2nd Enlarged Edition. Singapore: ISEAS, 2012.

Nashir, Haedar. Revitalisasi Gerakan Muhammadiyah. Yogyakarta: Bigraf Publishing, 1999.

Nashir, Haedar. Muhammadiyah Gerakan Pembaruan. Yogyakarta: Suara Muhammadiyah, 2010.

Nashir, Haedar. "Muktamar Teladan dan Muhammadiyah Berkemajuan,” dlm. Abdul Mu'ti et.al. eds. Kosmopolitanisme Islam Berkemajuan. Surakarta: Muhammadiyah University Press, 2015: 1-9.

Nashir, Haedar. "Muhammadiyah Membangun Integrasi Keislaman dan Kebangsaan Menuju Indonesia Berkemajuan,” dlm. Faozan Amar et.al. eds. Darul-Ahdi Wasy-Syahadah: Konteks, Makna dan Aktualisasi untuk Indonesia Berkemajuan. Jakarta: Al-Wasat Publishing House, 2018: 1932.

Peacock, James L. Muslim Puritans: Reformist Psychology in Southeast Asian Islam. Berkeley and Los Angeles, California: University of California Press, 1978a.

Peacock, James L. Purifying the Faith: The Muhammadijah Movement in Indonesian Islam. Menlo Park, California: Benjamin/Cummings Pub Co, 1978b.

Pimpinan Pusat Muhammadiyah. Tanfidz Keputusan Muktamar Satu Abad Muhammadiyah. Yogyakarta: Pimpinan Pusat Muhammadiyah, 2010.

Pimpinan Pusat Muhammadiyah. Indonesia Berkemajuan: Rekonstruksi Kehidupan yang Bermakna. Yogyakarta: Pimpinan Pusat Muhammadiyah, 2015.

Pimpinan Pusat Muhammadiyah. Negara Pancasila sebagai Darul Ahdi Wa Syahadah. Yogyakarta: Pimpinan Pusat Muhammadiyah, 2015. 
Pimpinan Pusat Muhammadiyah. Tanfidz Keputusan Muktamar Muhammadiyah ke-47. Yogyakarta: Pimpinan Pusat Muhammadiyah, 2015.

Pimpinan Pusat Muhammadiyah. "Data Amal Usaha Muhammadiyah,” dlm. Muhammadiyah http://www.muhammadiyah.or.id/content-8-det-amalusaha.html Diunduh pada 6 September 2018.

Piscatori, James. Islam in a World of Nation-States. Cambridge: Cambridge University Press, 1986.

Qodir, Zuly. Muhammadiyah Studies: Reorientasi Gerakan dan Pemikiran Memasuki Abad Kedua. Yogyakarta: Kanisius, 2010.

Rais M. Amien. Moralitas Politik Muhammadiyah. Yogyakarta: Dinamika, 1995.

Rais, Ahmad Imam Mujadid. “Pengantar Redaksi,” MAARIF, 11.1 (2016): 4-15.

Ricklefs, Merle C. "Foreword to the Second Edition: A Changing Society and a Changing Muhammadiyah,” dlm. Mitsuo Nakamura, The Crescent Arises over the Banyan Tree: A Study of the Muhammadiyah Movement in a Central Javanese Town, c.1910-2010, 2nd Enlarged Edition. Singapore: ISEAS, 2012.

Robison, Richard dan Vedi R. Hadiz. "Indonesia: A Tale of Misplaced Expectations,” The Pacific Review 30. 6 (2017): 895-909.

Saeed, Abdullah. "Trends in Contemporary Islam: A Preliminary Attempt at a Classification,” The Muslim World 97.3 (2007): 395-404.

Safi, Omid. Progressive Muslims: On Justice, Gender and Pluralism. Oxford: Oneworld, 2003.

Salim, Arskal. Challenging the Secular State: The Islamization of Law in Modern Indonesia. Honolulu: University of Hawai'i Press, 2009.

Al-Shaybani, Muhammed ibn al-Hasan. The Islamic Law of Nations, diterjemahkan Majid Khadduri. Baltimore, Maryland: Johns Hopkins University Press, 1966.

Syamsuddin, M. Din. "Gerakan Pencerahan Menuju Indonesia Berkemajuan: Refleksi, Proyeksi dan Rekomendasi,” dlm. Abdul Mu'ti et.al. eds. 
Kosmopolitanisme Islam Berkemajuan. Surakarta: Muhammadiyah University Press, 2015a: 10-26.

Syamsuddin, M. Din. "NKRI: Negara Perjanjian dan Kesaksian,” dlm. Akhmad Sahal dan Munawir Aziz, eds. Islam Nusantara: Dari Ushul Fiqh Hingga Konsep Historis. Bandung: Mizan, 2015b: 278-286.

Syamsuddin, M. Din. "Tafsir Islam atas Negara Pancasila," dlm. Muamaroh dan Benni Setiawan, eds. Negara Pancasila, Darul 'Ahdi Wasy-Syahadah: Perspektif Teologis dan Ideologis. Yogyakarta: Majelis Pendidikan Kader Pimpinan Pusat Muhammadiyah, 2017: 160-166.

Syuja. Islam Berkemajuan: Kisah Perjuangan KH Ahmad Dahlan dan Muhammadiyah Masa Awal. Jakarta: Al-Wasat, 2009.

Thohari, Hajriyanto Y. "Ia Bukan Muadzin Lagi,” dlm. Muhammad Najib et.al., Suara Amien Rais, Suara Rakyat. Jakarta, Gema Insani Press, 1999: 103106.

Thohari, Hajriyanto Y. “Trisula Baru Gerakan Muhammadiyah,” dlm. Abdul Mu'ti et.al. eds. Kosmopolitanisme Islam Berkemajuan. Surakarta: Muhammadiyah University Press, 2015: 329-333.

White, Jenny B. Islamist Mobilization in Turkey: A Study in Vernacular Politics. Washington, DC: The University of Washington Press, 2002.

Yamien, M. Nurul. "Muhammadiyah dan Masyarakat Informasi,” Republika. 3 Mei 2010.

ZTF., Pradana Boy. "Another Face of Puritan Islam: Muhammadiyah and Radicalism among the Youth," International Research Conference on Muhammadiyah. Malang: The University of Muhammadiyah Malang, 2012. 


\section{Wawancara}

Wawancara dengan aktivis Muhammadiyah (yang memohon identitasnya untuk tidak dipublikasikan), 30 Agustus 2018.

Wawancara dengan Abd. Rohim Ghazali, 30 Agustus 2018.

Wawancara dengan Abdul Munir Mulkhan, 22 September 2018.

Wawancara dengan Azaki Khoiruddin, 28 Agustus 2018.

Wawancara dengan Hajriyanto Y. Thohari, 21 Agustus 2018.

Wawancara dengan Mu'arif, 20 Agustus 2018.

Wawancara dengan Saad Ibrahim, 23 Agustus 2018.

Wawancara dengan Zuly Qodir, 30 Agustus 2018. 